\title{
MBD1 Contributes to the Genesis of Acute Pain and Neuropathic Pain by Epigenetic Silencing of Oprm1 and Kcna2 Genes in Primary Sensory Neurons
}

\author{
ㅈai Mo, ${ }^{1,2,3 *}$ 이 Shaogen Wu, ${ }^{1 *}$ Xiyao Gu, ${ }^{1 *}$ Ming Xiong, ${ }^{1 *}$ Weihua Cai, ${ }^{1,4}$ Fidelis E. Atianjoh, ${ }^{1}$ Emily E. Jobe, ${ }^{5}$ \\ Xinyu Zhao, ${ }^{5}$ Wei-Feng Tu, ${ }^{2}$ and $\odot$ Yuan-Xiang Tao ${ }^{1}$ \\ ${ }^{1}$ Department of Anesthesiology, New Jersey Medical School, Rutgers State University of New Jersey, Newark, New Jersey 07013, ${ }^{2}$ Department of \\ Anesthesiology, Guangzhou General Hospital of Guangzhou Military Region, Southern Medical University, Guangzhou 510010, China, ${ }^{3}$ Department of \\ Anesthesiology, Zhujiang Hospital, Southern Medical University, Guangzhou 510282, China, ${ }^{4}$ Neuroscience Research Institute, Zhengzhou University \\ Academy of Medical Sciences, Zhengzhou 450006, China, and ${ }^{5}$ Department of Neuroscience, University of Wisconsin-Madison, Madison, Wisconsin 53705
}

The transmission of normal sensory and/or acute noxious information requires intact expression of pain-associated genes within the pain pathways of nervous system. Expressional changes of these genes after peripheral nerve injury are also critical for neuropathic pain induction and maintenance. Methyl-CpG-binding domain protein 1 (MBD1), an epigenetic repressor, regulates gene transcriptional activity. We report here that MBD1 in the primary sensory neurons of DRG is critical for the genesis of acute pain and neuropathic pain as DRG MBD1-deficient mice exhibit the reduced responses to acute mechanical, heat, cold, and capsaicin stimuli and the blunted nerve injury-induced pain hypersensitivities. Furthermore, DRG overexpression of MBD1 leads to spontaneous pain and evoked pain hypersensitivities in the WT mice and restores acute pain sensitivities in the MBD1-deficient mice. Mechanistically, MDB1 represses Oprm1 and Kcna2 gene expression by recruiting DNA methyltransferase DNMT3a into these two gene promoters in the DRG neurons. DRG MBD1 is likely a key player under the conditions of acute pain and neuropathic pain.

Key words: acute pain; DRG; Kv1.2; MBD1; mu opioid receptor; neuropathic pain

Significance Statement

In the present study, we revealed that the mice with deficiency of methyl-CpG-binding domain protein 1 (MBD1), an epigenetic repressor, in the DRG displayed the reduced responses to acute noxious stimuli and the blunted neuropathic pain. We also showed that DRG overexpression of MBD1 produced the hypersensitivities to noxious stimuli in the WT mice and rescued acute pain sensitivities in the MBD1-deficient mice. We have also provided the evidence that MDB1 represses 0 prm1 and Kcna2 gene expression by recruiting DNA methyltransferase DNMT3a into these two gene promoters in the DRG neurons. DRG MBD1 may participate in the genesis of acute pain and neuropathic pain likely through regulating DNMT3a-controlled 0 prm 1 and $K c n a 2$ gene expression in the DRG neurons.

\section{Introduction}

Pain, a distressing feeling, is the most prevalent symptom that prompts people to seek medical attention and avoid harmful activities. During the pain signaling pathways, the transmission of

Received April 5, 2018; revised Sept. 12, 2018; accepted Sept. 24, 2018.

Author contributions: K.M. and Y.-X.T. wrote the first draft of the paper; W.-F.T. and Y.-X.T. edited the paper; K.M., S.W., X.G., M.X., W.-F.T., and Y.-X.T. designed research; K.M., S.W., X.G., M.X., W.C., F.E.A., E.E.J., X.Z., and W.-F.T. performed research; Y.-X.T. contributed unpublished reagents/analytic tools; K.M., S.W., X.G., M.X., W.C., F.E.A., W.-F.T., and Y.-X.T. analyzed data; Y.-X.T. wrote the paper.

This work was supported by National Institutes of Health Grants R01NS094664, R01NS094224, and R01DA033390 to Y.-X.T., and Natural Science Foundation of Guangdong Province in China 2017 A030313599 and Southern Medical University in China Young Scientist and Technician Training Program PY2016N014 to K.M.

The authors declare no competing financial interests.

*K.M., S.W., X.G., and M.X. contributed equally to this study. acute noxious information requires intact expression of the painassociated genes encoding receptors (e.g., mu opioid receptor [MOR]), ion channels (e.g., Kv1.2), and neurotransmitters (e.g., glutamate transporters) (Mansikka et al., 2004; Liaw et al., 2005; Tao et al., 2005; X. Zhao et al., 2013; Fan et al., 2014). Moreover, peripheral nerve injury produces transcriptional changes in the

Correspondence should be addressed to either of the following: Dr. Yuan-Xiang Tao, Department of Anesthesiology, New Jersey Medical School, Rutgers State University of New Jersey, 185 South Orange Avenue, MSB, E-661 Newark, NJ 07103, E-mail: yuanxiang.tao@njms.rutgers.edu; or Dr. Wei-Feng Tu, Department of Anesthesiology, Guangzhou General Hospital of Guangzhou Military Region, Southern Medical University, Guangzhou 510010 China, E-mail:wftuyx02@163.com.

https://doi.org/10.1523/JNEUROSCI.0880-18.2018

Copyright $\odot 2018$ the authors $\quad 0270-6474 / 18 / 389883-17 \$ 15.00 / 0$ 
expression of pain-associated genes in the DRG, dorsal horn of spinal cord, and other pain-related brain regions (Alvarado et al., 2013; Wu et al., 2016; Yin et al., 2016; Descalzi et al., 2017). These changes contribute to the induction and maintenance of neuropathic pain (Lutz et al., 2014; Mauck et al., 2014; Liang et al., 2015). Therefore, it is crucial to understand how these painassociated genes are kept at normal expressional level under acute pain conditions and how their expression is altered under neuropathic pain conditions.

Epigenetic modifications, such as DNA methylation, participate in the mechanisms for gene regulation (Poetsch and Plass, 2011; Liang et al., 2015). In mammalian cells, a group of DNA methyltransferases (DNMTs), including DNMT1, DNMT3a, and DNMT3b, catalyze DNA at the carbon-5 position of cytosine residues situated adjacent to a guanine residue (CpG site), resulting in the formation of 5-methylcytosine. DNA methylation suppresses gene transcription through several mechanisms, including serving as docking sites for transcriptional repressors/ corepressors, such as the methyl-CpG-binding domain (MBD) family of proteins (Turek-Plewa and Jagodzinski, 2005; Jeltsch, 2006; Siedlecki and Zielenkiewicz, 2006; Poetsch and Plass, 2011). The MBD family of proteins contain MBD1-4 and methyl-CpG-binding protein 2 (MeCP2). Each of these proteins has a specific domain of $\sim 70$ residues, which directly binds to one or more methylated CpGs of a gene promoter. The MBD family of proteins recruit other transcriptional corepressors, such as histone deacetylases, to the promoter region of the targeted gene for its silencing (Turek-Plewa and Jagodzinski, 2005). Thus, the MBD family of proteins is likely required for DNA methylationtriggered gene transcriptional repression.

Although recent evidence shows the contribution of DRG DNA methylation to chronic pain (Qi et al., 2013; Zhou et al., 2014; Liang et al., 2015; Sun et al., 2017; B. Xu et al., 2017; J. Y. Zhao et al., 2017), whether and how MBD family of proteins are involved in chronic pain are still uncertain. MeCP2 is closely related to Rett syndrome, a neurodevelopmental disease that is primarily caused by mutations of the MeCP2 locus (Downs et al., 2010; Cuddapah et al., 2014). The patients with Rett syndrome exhibited decreased pain sensitivities (Downs et al., 2010; Cuddapah et al., 2014). Consistently, the Mecp2 mutant mice also displayed decreased pain sensitivity (Manners et al., 2015; M. Xu et al., 2017). Interestingly, specific deletion of Mecp2 in somatosensory neurons produced tactile hypersensitivity (Orefice et al., 2016). The expression of MeCP2 and the levels of its phosphorylation were increased in the dorsal horn of spinal cord under chronic inflammatory pain conditions (Géranton et al., 2008; Tochiki et al., 2012). In contrast, the change in MeCP2 expression under neuropathic pain conditions is controversial. An increase in $\mathrm{MeCP} 2$ expression was seen in the spinal cord following chronic constriction injury of sciatic nerve (Wang et al., 2011, 2016), whereas a reduction was observed in the superficial dorsal horn of spinal cord following spared nerve injury (Tochiki et al., 2012). In addition, systemic MeCP 2 overexpression reduced both acute pain and neuropathic pain (Zhang et al., 2015), whereas Mecp2 heterozygous mice displayed the loss of complete Freund's adjuvant (CFA)-induced heat hyperalgesia (Suzuki et al., 2016). Thus, the role of MBD family of proteins in chronic pain remains to be clarified.

Here, we report that DRG MBD1 expression is required for the genesis of acute pain and neuropathic pain likely through regulating DNMT3a-controlled Oprm1 and Kcna2 gene expression in the DRG neurons. DRG MBD1 likely is an endogenous contributor to the genesis of both acute pain and neuropathic pain.

\section{Materials and Methods}

Animals. $\mathrm{Mbd1}^{-1-}$ mice, provided by Dr. Xinyu Zhao (Department of Neuroscience, University of Wisconsin-Madison, Madison, WI), have been bred onto C57B/L6 background for at least 6 generations (X. Zhao et al., 2003) and were bred by crossing the heterozygotes in our facility. Both male and female $M b d 1^{-1-}$ mice are viable and fertile with normal appearance and locomotor activity (X. Zhao et al., 2003). Male $M b d 1^{-1-}$ mice and the WT control littermates mice weighing 25-30 g (2-3-months of age) were used for the experiments. All animals were kept in a standard $12 \mathrm{~h}$ light/dark cycle, with water and food pellets available ad libitum. All procedures used were approved by the Animal Care and Use Committee at Rutgers State University of New Jersey, and consistent with the ethical guidelines of the National Institutes of Health and the International Association for the Study of Pain. All efforts were made to minimize animal suffering and to reduce the number of animals used. During behavioral testing, all experimenters were blind to viral treatment and/or mouse genotypes.

Animal models. L4 spinal nerve ligation (SNL) model of neuropathic pain in mice was performed as described previously (Rigaud et al., 2008; Sun et al., 2017; J. Y. Zhao et al., 2017). Briefly, the mice were anesthetized with isoflurane and placed in a prone position. A dorsolateral skin incision was made on the lower back. The L4 transverse process was identified and freed of its muscle attachments and then removed. The underlying L4 nerve root was isolated, ligated with a 7-0 silk suture, and transected just distal to the ligature. Sham animals received an identical surgery of the SNL group, but without the ligature of the L4 spinal nerve. The capsaicin-induced acute pain model in mice was performed as described previously (Cui et al., 2016). After $10 \mu \mathrm{l}$ of capsaicin $(0.1 \mu \mathrm{g} / \mu \mathrm{l}$ in normal saline/5\% ethanol, Sigma-Aldrich, M2028) solution was subcutaneously injected into the plantar side of one hindpaw, the number of shakes and flinches and the duration of lifting of ipsilateral hindpaw were recorded for the first $10 \mathrm{~min}$ after injection. Paw withdrawal responses to mechanical and thermal stimuli, as described below, were measured 30 min after capsaicin injection. The CFA-induced inflammatory pain model in mice was performed as described previously (Chu et al., 2005; Cui et al., 2016). A $10 \mu \mathrm{l}$ of 50\% emulsified CFA (Sigma-Aldrich, F5881; dissolved in normal saline) solution was injected subcutaneously into the plantar side of one hindpaw. A $10 \mu \mathrm{l}$ normal saline was used as a control. The formalin-induced pain model in mice was performed as described previously (Cui et al., 2016). The mice received the injection of $0.6 \%$ formalin $10 \mu \mathrm{l}$ (normal saline was used for control) into the plantar side of one hindpaw. The number of paw flinches and shakes were immediately counted every $5 \mathrm{~min}$ for $1 \mathrm{~h}$. The observational session was divided into two phases: the first $(0-10 \mathrm{~min})$ and the second $(10-60 \mathrm{~min})$ phase. The model of morphine-induced analgesia and tolerance in mice was performed as described previously (Liaw et al., 2008; Liang et al., 2016b). Briefly, for morphine-induced analgesic test, paw withdrawal latency (PWL), as described below, was measured 20 min after subcutaneous injection of $1 \mathrm{mg} / \mathrm{kg}$ morphine. For the morphine-induced tolerance, the mice received subcutaneous injection of $10 \mathrm{mg} / \mathrm{kg}$ morphine twice daily for $8 \mathrm{~d}$. Tail flick latency, as described below, was measured before morphine injection and $20 \mathrm{~min}$ after morphine injection on the mornings of day $1,3,5,7$, and 8 .

Behavioral analysis. Mechanical, cold, thermal, tail flick tests and locomotor performance were performed before viral microinjection or surgery and at a different time points after surgery. Each behavioral test was performed at $1 \mathrm{~h}$ intervals.

Paw withdrawal frequencies (PWFs) in response to mechanical stimuli (calibrated von Frey filaments) were first measured as described previously (Liaw et al., 2008; Li et al., 2017). Briefly, the animals were placed in an individual Plexiglas chamber on a raised mesh screen. Two calibrated von Frey filaments ( 0.07 and $0.4 \mathrm{~g}$; Stoelting) were used to stimulate the hindpaw for $\sim 1 \mathrm{~s}$, and each stimulation was repeated 10 times to both hindpaws with $5 \mathrm{~min}$ intervals. Paw withdrawal response in each of these 10 applications was represented as a percentage response frequency $[($ number of paw withdrawals $/ 10$ trials $) \times 100=\%$ response frequen- 
cies], and this percentage was obtained as an indication of the amount of paw withdrawal.

PWLs in response to noxious thermal stimuli were examined as described previously (Liaw et al., 2008; Li et al., 2017). In brief, the mice were placed in a Plexiglas chamber on a glass plate. A radiant heat from model 336 Analgesic Meter (IITC Life Science) was applied by aiming a beam of light through a hole in the light box through the glass plate to the middle of the plantar surface of each hindpaw. When the animal lifted its foot, the light beam was automatically turned off. The length of time between the start of the light beam and the foot lift was defined as the PWL. For each side, 5 trials with 5 min interval were performed, and setting $20 \mathrm{~s}$ cutoff time was used to avoid tissue damage to the hindpaw.

PWLs to noxious cold $\left(0^{\circ} \mathrm{C}\right)$ were measured with a cold aluminum plate on ice as previously described (Li et al., 2017). Each animal was placed in a Plexiglas chamber on the cold plate, the temperature of which was monitored continuingly by a thermometer, which was set at $0^{\circ} \mathrm{C}$. The duration of time between the placement of the hindpaw on the plate and the animal jumping, with or without paw licking and flinching, was defined as the PWL. Each trial was repeated three times at $10 \mathrm{~min}$ intervals for the paw on the ipsilateral side. A cutoff time of $20 \mathrm{~s}$ was set to avoid tissue damage.

The tail flick test was performed on an apparatus (model 33B Tail Flick Analgesic Meter, IITC Life Science) with a radiant heat source connected to an automatic timer as described previously (Liaw et al., 2008). A cutoff time latency of $10 \mathrm{~s}$ was used to avoid tissue damage to the tail. Tail flick latencies were measured as the time required to induce a tail flick after applying radiant heat to the skin of the tail. The antinociceptive effects were expressed as the percentage of maximal possible analgesic effect ( $\%$ MPAE $): \%$ MPAE $=[($ response latency - baseline latency $) /($ cutoff latency - baseline latency)] $\times 100 \%$.

Locomotor functional activities were examined through three reflex tests as previously described (Li et al., 2017). (1) Placing reflex: The mice were held with the hind limbs slightly lower than the forelimbs, and the dorsal surfaces of the hindpaws were brought into contact with the edge of a table. The experimenters observed whether the hindpaws were placed on the table surface reflexively. (2) Grasping reflex: The mice were placed on a wire grid, and the experimenters noted whether the hindpaws grasped the wire on contact. (3) Righting reflex: The mice were placed on their back on an even surface, and the experimenters recorded whether they immediately assumed the normal upright position. Scores for placing, grasping, and righting reflexes were based on counts of each normal reflex exhibited in five trials.

Conditioned place preference test was performed as our previous described with minor modification (Li et al., 2017). Briefly, an apparatus with two Plexiglas chambers connected with an internal door (Med Associates) was used. One of the chambers was made of rough floor and walls with black and white horizontal stripes on, and another one was composed of smooth floor and walls with black and white vertical stripes on. Movement of the mice and time spent in each chamber were monitored by photobeam detectors installed along the chamber walls and automatically recorded in MED-PC IV conditioned place preference software. Mice were first preconditioned for $30 \mathrm{~min}$ to habituate the environment with full access to two chambers. At the end of preconditioning, basal duration time spent in each chamber was recorded within 15 min to check whether mice had a preexisting chamber bias. Animals spending $>80 \%$ or $<20 \%$ of the total time in any chamber were excluded from further testing. The conditioning protocol was performed for the following $3 \mathrm{~d}$ when the internal door was closed. The mice first received intrathecal injection of saline $(5 \mu \mathrm{l})$ specifically paired with one conditioning chamber in the morning. At $6 \mathrm{~h}$ later, lidocaine $(0.8 \%$ in $5 \mu \mathrm{l}$ saline) was given intrathecally paired with another opposite conditioning chamber in the afternoon. Injection order of saline and lidocaine every day was switched. On the test day (at least $20 \mathrm{~h}$ after pairing), mice were placed in the chamber with door open so animals can have free access to all chambers. Movement and duration of each mouse spent in each chamber were recorded for $15 \mathrm{~min}$ for analysis of chamber preference. Difference scores were calculated as (test time - preconditioning time) spent in the drug chamber.
DRG microinjection. DRG microinjection was performed as described with minor modification (Liang et al., 2016a; Li et al., 2017). Briefly, a midline incision was made in the lower lumbar back region, and the $\mathrm{L}_{3}$ and/or $\mathrm{L}_{4}$ articular processes were exposed and then removed with small forceps. After the DRG was exposed, viral solution ( $0.5 \mu$ l each site) was injected into two sites in the $\mathrm{L}_{3}$ and $\mathrm{L}_{4}$ DRGs with a glass micropipette connected to a Hamilton syringe. The pipette was retained for $10 \mathrm{~min}$. After injection, the surgical field was irrigated with sterile saline and the skin incision closed with wound clips. The injected mice displayed no sign of paresis or other abnormalities.

For siRNA injection, $M b d 1$ siRNA (catalog \#sc-35864) and its negative control (NC) siRNA (catalog \#sc-44230) were purchased from Santa Cruz Biotechnology. To improve delivery and prevent degeneration of siRNA, TurboFect in vivo transfection reagent (Thermo Fisher Scientific) was used as a delivery vehicle as described previously (Li et al., 2017).

Plasmid constructs and virus production. Mouse Mbdl cDNA was synthesized and amplified from the total RNA of mouse DRG using the SuperScript III One-Step RT-PCR System with the Platinum Taq High Fidelity Kit (Invitrogen) and the primers (Table 1). A second PCR step was performed using the Platinum $P f x$ DNA Polymerase (Invitrogen) and the primers (Table 1). Fragments harboring full-length $M b d 1$ was ligated into the proviral plasmids (University of North Carolina, Chapel Hill, NC) using the BspEI and NotI restriction sites (New England Biolabs). The resulting vectors expressed the genes under the control of the cytomegalovirus promotor. Recombinant adeno-associated virus Type 5 (AAV5) viral particles carrying the Mbd1 cDNAs were produced at the University of North Carolina Vector Core. AAV5 viral particles carrying enhanced GFP was purchased from University of North Carolina Vector Core. Herpes simplex virus (HSV)-GFP and HSV-Dnmt3a were provided by Dr. Eric J Nestler.

RNA extraction and RT-PCR. RNA extraction and reverse transcription RT-PCR were performed according to our previously published protocols (Liang et al., 2016a; Li et al., 2017). Total RNA from tissues or culture cells were extracted using miRNeasy Mini Kit (QIAGEN) and reverse-transcribed using the Thermo Script reverse transcriptase (Invitrogen) follow the manufacturer's instructions with either the Oligo(dT) primers or specific reverse primers (Table 1). cDNA was amplified in a Bio-Rad CFX96 real-time PCR system using the primers listed in the Table 1 (Integrated DNA Technologies). GAPDH was used as an internal control. Each sample was run in triplicate in a $20 \mu \mathrm{l}$ reaction with $250 \mathrm{nM}$ forward and reverse primers, $10 \mu \mathrm{l}$ of SsoAdvanced Universal SYBR Green Supermix (Bio-Rad), and 20 ng of cDNA. The cycle parameters were set as follows: an initial $3 \mathrm{~min}$ incubation at $95^{\circ} \mathrm{C}$, followed by 40 cycles of $95^{\circ} \mathrm{C}$ for $10 \mathrm{~s}, 60^{\circ} \mathrm{C}$ for $30 \mathrm{~s}$, and $72^{\circ} \mathrm{C}$ for $30 \mathrm{~s}$. Relative changes of mRNA levels were calculated by using the $\Delta \mathrm{Ct}$ method $\left(2^{-\Delta \Delta \mathrm{Ct}}\right)$.

For single-cell real-time RT-PCR, freshly dissociated DRG neurons from adult mice were first prepared as described previously (Liang et al., 2016a; Li et al., 2017). Briefly, $4 \mathrm{~h}$ after plating, a single living small DRG neuron was collected under an inverted microscope fit with a micromanipulator and microinjector and placed in a PCR tube with 5-10 $\mu$ l of cell lysis buffer (Signosis). After centrifugation, the supernatants were collected. The remaining real-time RT-PCR procedure was performed following the manufacturer's instructions with the single-cell real-time RT-PCR assay kit (Signosis). All primers used are listed in Table 1.

DRG neuronal culture and transfection. Primary DRG neuronal cell cultures and viral transduction were performed as described previously (Liang et al., 2016a; Li et al., 2017). Briefly, all DRGs from cervical to lumbar levels were collected in cold Neurobasal medium (Invitrogen/ Thermo Fisher Scientific) with 10\% FBS (Invitrogen/Thermo Fisher Scientific), 2\% B-27 supplement (Invitrogen/Thermo Fisher Scientific), 1\% L-glutamine (Invitrogen/Thermo Fisher Scientific), 100 units/ml penicillin, $100 \mu \mathrm{g} / \mathrm{ml}$ streptomycin (Invitrogen/Thermo Fisher Scientific) after adult WT or $M b d 1^{-1-}$ mice were killed with isoflurane. The DRGs were then treated with enzyme solution containing collagenase Type I ( $1 \mathrm{mg} /$ $\mathrm{ml}$ ) and dispase $(5 \mathrm{mg} / \mathrm{ml})$ in Hanks' balanced salt solution (HBSS) (Invitrogen/Thermo Fisher Scientific). After trituration and centrifugation, the dissociated cells were resuspended in mixed neurobasal medium and plated at a density of $1.5 \times 10^{5}$ to $4 \times 10^{5}$ cells on glass coverslips (for calcium image experiment or whole-cell patch-clamp recording) or in a 
Table 1. All primers used ${ }^{a}$

\begin{tabular}{|c|c|c|c|}
\hline Name & Sequence $\left(5^{\prime}\right.$ to $\left.3^{\prime}\right)$ & Name & Sequence $\left(5^{\prime}\right.$ to $\left.3^{\prime}\right)$ \\
\hline$P C R / R T-P C R$ & & $C h I P P C R$ & \\
\hline Gapdh RT & TCGTGGTTCACACCCATCAC & Oprm1 ChIPF & CCTCAGATATGGGGATGTGG \\
\hline Kсna2 RT & GTCCCCGTCACATCTTCTCACT & Oprm1 ChIPR & ATCAGCCAGGAAAGTCGTTG \\
\hline Kcna4 RT & GGATGCTGTCCGGTGATGAC & Kena2 ChIP R & GGAGACAGGGGAGAGGGTAG \\
\hline Gapdh F & TCGGTGTGAACGGATTTGGC & Cloning & \\
\hline Gapdh R & TCCCATTCTCGGCCTTGACT & Oprm1 promoter F & ATAGGTACCGGCACATGAAACAGGCTTCT \\
\hline Kena1 F & AGGAGAAGGACGGGAAACGC & Kcna2 promoter $R$ & AGCAAGCTTTGGGTTAGATCCCTGTGTCC \\
\hline Kcna1 R & CGATCGATGGACGCTGGC & Mbd1 RT F & CACTGGTGGAGGAGGAAGAG \\
\hline Knca4 F & TGCTGGGAATGGTGAAGTGC & Mbd1 RT R & TCCTGAATTCCAGGTTCAGC \\
\hline Knca4 R & CCCACAGACAATGCCAGGTT & Mbd1 NF & ATATCCGGAGCCACCATGGCTGAGTCCTGGCA \\
\hline Oprm1 F & TCTTCACCCTCTGCACCATG & Mbd1 NR & CGCCAGCGGCCGCCTACAAAACTTCTTCTTTC \\
\hline Oprm1 R & TCTATGGACCCCTGCCTGTA & ISHH probe & \\
\hline $\mathrm{Mbd1} \mathrm{F}$ & CTGCATCTGCGTCTTCACAT & & \\
\hline Mbd1 R & САCACCCCACAGTCCTCTTT & & \\
\hline Dnmt3aF & GCCAAGAAACCCAGAAAGAGC & & \\
\hline Dnmt3a R & GCACATGCCTCCAATGAAGA & & \\
\hline
\end{tabular}

${ }^{a} \mathrm{RT}$, Reverse transcription; $\mathrm{F}$, forward; $\mathrm{R}$, reverse; $\mathrm{N}$, nested. Underlined letters indicate the restriction enzyme recognition sites.

six-well plate coated with poly-D-lysine (50 $\mu \mathrm{g} / \mathrm{ml}$, Sigma-Aldrich) for viral transfection or cAMP measurement. The cells were incubated in an incubator $\left(95 \% \mathrm{O}_{2} / 5 \% \mathrm{CO}_{2}\right)$ at $37^{\circ} \mathrm{C}$. One day later, the drugs or virus $\left(0.5-2 \mu \mathrm{l}\right.$, titer $\left.\geq 1 \times 10^{12} / \mathrm{ml}\right)$ was added to each well based on the experimental design. Cells were collected for detecting mRNA or protein at 48 or $72 \mathrm{~h}$ later.

Chromatin immunoprecipitation assay. The chromatin immunoprecipitation assays were conducted by using the EZ ChIP Kit (Millipore) as described previously (Liang et al., 2016a; Li et al., 2017). The homogenization DRG solution from the WT and $M b d 1^{-1-}$ mice was cross-linked with $1 \%$ formaldehyde at $37^{\circ} \mathrm{C}$ for $10 \mathrm{~min}$ and the reaction terminated by the addition of $0.25 \mathrm{~m}$ glycine. After centrifugation, the pellets were collected, washed, and suspended in lysis buffer containing 0.1\% SDS, $1 \%$ sodium deoxy cholate, and $1 \% \mathrm{NP}-40$ in the presence of protease inhibitors. The suspension was sonicated to shear chromatin and produce $0.2-1 \mathrm{~kb}$ DNA fragments. After the samples were precleared with protein G agarose, they were immunoprecipitated with $5 \mu \mathrm{g}$ of rabbit anti-MBD1 antibody (sc-10751, Santa Cruz Biotechnology) or normal rabbit serum. Input ( $10 \%$ of the sample for immunoprecipitation) was used as a positive control. The fragment of Oprm1 and Kcna2 gene promoters containing the predicted MBD1 binding sites was detected by PCR with the primers listed in Table 1.

Cresyl violet histochemical staining. The $\mathrm{WT}$ and $M b d 1^{-1-}$ mice were deeply anesthetized with isoflurane and transcardially perfused with $50-$ $100 \mathrm{ml}$ of $4 \%$ PFA in $0.1 \mathrm{~m}$ PBS, pH 7.4. The DRG was removed, postfixed overnight at $4^{\circ} \mathrm{C}$, and cryoprotected in $30 \%$ sucrose in $0.1 \mathrm{M}$ PBS overnight. Two sets of $20 \mu \mathrm{m}$ sections were harvested from each DRG by grouping every third sections ( 3 or 4 sections per set per DRG). Each set (one set for the morphological observation and another for counting number of stained cells) was subjected to cresyl violet (Nissl) staining as described previously (Liaw et al., 2005) with slight modification. Briefly, after being dehydrated, the sections were stained in $0.1 \%$ cresyl violet solution at $37^{\circ} \mathrm{C}$ for $30 \mathrm{~min}$. The sections were then rinsed in distilled water for 2 times and differentiated in 95\% ethyl alcohol with 2 drops glacial acetic acid for $15 \mathrm{~min}$. The morphology of the stained cells was observed under a light microscope. The number of the stained cells with the nucleus was counted randomly in a specific size of rectangular area $\left(130 \times 160 \mu \mathrm{m}^{2}\right)$ with the staining cells.

Immunohistochemistry. The sections from the DRG and spinal cord of the WT and $M b d 1^{-1-}$ mice were prepared as described above. All the sections were blocked for $1 \mathrm{~h}$ at $25^{\circ} \mathrm{C}$ in $0.01 \mathrm{~m}$ PBS containing $10 \%$ goat serum and $0.3 \%$ Triton X-100 before being incubated with the guinea pig anti-MOR antibody (1:1000; Millipore), rabbit anti-Kv1.2 antibody (1: 200; Alomone Labs), rabbit anti-NF200 (1:100, Sigma-Aldrich), biotinylated IB4 (1:200, Sigma-Aldrich), or mouse anti-calcitonin gene-related peptide (CGRP, 1:200, Abcam) overnight at $4^{\circ} \mathrm{C}$. The sections were then incubated with goat anti-rabbit, anti-guinea pig, or anti-mouse IgG conjugated with Cy3 (1:200, Jackson ImmunoResearch Laboratories) or with FITC-labeled Avidin D (1:200, Sigma-Aldrich) for $1 \mathrm{~h}$ at room temperature. Control experiments included omission of the primary antiserum and substitution of normal guinea pig, rabbit serum, or mouse serum for the primary antiserum. All immunofluorescence-labeled images were examined under the DMI 4000 fluorescence microscope (Leica Microsystems) and captured with the DFC365FX camera (Leica Microsystems). Positive neuron counting and integrated densities after background subtraction were performed by National Institutes of Health ImageJ Software.

ISH histochemistry. ISH histochemistry was performed as described previously (X. Zhao et al., 2013; Li et al., 2017). Briefly, the Mbd1 antisense RNA probe $(0.433 \mathrm{~kb})$ was first prepared by in vitro transcription and labeled with digoxigenin-dUTP according to the manufacturer's instructions (Roche Diagnostic). Primers are listed in Table 1. Bilateral L3/4 DRGs from WT and $M b d 1^{-1-}$ mice were harvested for the single labeling of Mbd1 mRNA and double labeling of Mbd1 mRNA with DRG marker immunohistochemistry. For the single labeling, after treatment of proteinase $\mathrm{K}$ and prehybridization, the sections $(20 \mu \mathrm{m}$ at the thickness) were hybridized with digoxigenin-dUTP-labeled $M b d 1$ antisense RNA probe $(2 \mathrm{ng} / \mu \mathrm{l})$ overnight at $67^{\circ} \mathrm{C}$. After being washed, the sections were then incubated with alkaline-phosphatase-conjugated anti-digoxigenin antibody (1:1000) overnight. The fluorescent signals were finally developed with HNPP/Fast Red (Roche Diagnostic) in detection buffer 30 min twice. The sections were then rinsed in PBS and mounted with antifade mounting medium with 4',6-diamidino-2phenylindole (DAPI, Vector Laboratories). For the double labeling, all protocols before being blocked with PBT containing 10\% normal goat serum are similar to those for the single labeling. The sections were then incubated with alkaline-phosphatase-conjugated anti-digoxigenin (1: 1000, Roche Diagnostic) and chicken anti- $\beta$ tubulin III (1:500, EMD Millipore), rabbit anti-glutamine synthetase (GS, 1:500, Sigma-Aldrich), rabbit anti-NF200 (1:100, Sigma-Aldrich), biotinylated IB4 (1:200, Sigma-Aldrich), or mouse anti-CGRP (1:200, Abcam) at $4^{\circ} \mathrm{C}$ overnight in $20 \%$ goat serum blocking solution. After being washed, the sections 
were incubated with species-appropriate FITC or Cy2-conjugated secondary antibody (1:500) or with FITC-labeled Avidin D (1:200, SigmaAldrich) for $1 \mathrm{~h}$ at room temperature followed by HNPP/FastRed detection.

Western blotting. The tissues or cultured neuron cells were homogenized in the lysis buffer containing $10 \mathrm{~mm}$ Tris, $1 \mathrm{~mm} \mathrm{PMSF,} 5 \mathrm{~mm} \mathrm{MgCl}_{2}$, $5 \mathrm{~mm}$ EGTA, $1 \mathrm{~mm}$ EDTA, $1 \mathrm{~mm}$ DTT, $40 \mu \mathrm{m}$ leupeptin, and $250 \mathrm{~mm}$ sucrose. After centrifugation at $4^{\circ} \mathrm{C}$ for $15 \mathrm{~min}$ at $1000 \times \mathrm{g}$, the supernatant was collected for cytosolic proteins and the pellets were sonicated in the lysis buffer plus $1 \%$ SDS and $0.1 \%$ Triton X-100 for nuclear proteins. After protein concentration was measured, the samples were heated at $99^{\circ} \mathrm{C}$ for $5 \mathrm{~min}$ and loaded onto a $4 \%-15 \%$ stacking $/ 7.5 \%$ separating SDS-polyacrylamide gel (Bio-Rad). The proteins were then electrophoretically transferred onto a PVDF membrane (Bio-Rad). According to the targeted protein molecular weights, the membranes were cut into several small strips and then blocked with $3 \%$ nonfat milk in TBS containing $0.1 \%$ Tween 20 for $1 \mathrm{~h}$. The following primary antibodies were used: mouse anti-Kv1.1 (1:200, NeuroMab), mouse anti-Kv1.2 (1:200, NeuroMab), mouse anti-Kv1.4 (1:300, NeuroMab), rabbit anti-MOR (1:500, Neuromics), rabbit anti- $\kappa$ opioid receptor (KOR) (1:500, Novus Biologicals), rabbit anti-GAPDH $(1: 1000 ; \sigma)$, mouse anti-MBD1 (1:500, gift from the X.Z. laboratory), rabbit anti-DNMT3a (1:500, Cell Signaling Technology), and rabbit anti-histone H3 (1:1000, Cell Signaling Technology). The proteins were detected by HRP-conjugated antimouse or anti-rabbit secondary antibody (1:3000 Jackson ImmunoResearch Laboratories) and visualized with peroxide reagent and luminol/enhancer reagent (Clarity Western ECL Substrate, Bio-Rad) using a ChemiDoc XRS System (Bio-Rad). The intensity of blots was quantified with densitometry by System with Image Lab software (Bio-Rad). The band intensities for cytosol proteins were normalized to GAPDH and those for nucleus proteins to total histone $\mathrm{H} 3$.

Luciferase assay. To construct the Oprm1 and Kcna2 gene reporter plasmids, we amplified the fragments from the Oprm1 and Kcna2 gene promoter (including the MBD1-binding motif) by PCR from genomic DNA. The PCR products were cloned into the KpnI and HindIII restriction sites of the pGL3-Basic vector (Promega). After the sequences of recombinant clones were verified, both constructs were prepared using Plasmid Midi Kit (QIAGEN) and in vitro methylated by CpG methyltransferase M.SssI (New England Biolabs). A catecholaminergic cell (CAD) line derived from central nervous neurons was cultured in DMEM/F-12 medium (catalog 11330-032; Invitrogen/Thermo Fisher Scientific), supplemented with $10 \%$ FBS (JR Scientific), 100 units $/ \mathrm{ml}$ penicillin, and $100 \mu \mathrm{g} / \mathrm{ml}$ streptomycin (Quality Biological) on 12-well plates in a humidified 5\% $\mathrm{CO}_{2}$ incubator. Each well was transfected with $300 \mathrm{ng}$ of the constructed overexpression plasmid and luciferase gene reporter plasmid along with $10 \mathrm{ng}$ of the pRL-TK plasmid (a normalizing control; Promega) using Lipofectamine 2000 (Invitrogen). After $48 \mathrm{~h}$ culture, the transfected cells were lysed with passive lysis buffer and $10 \mu \mathrm{l}$ supernatant was assayed for luciferase activity with the dual-luciferase reporter assay system (Promega). The relative reporter activity was obtained by normalization of the firefly activity to Renilla activity with a Centro XS3 LB 960 Microplate Luminometer (Berthold Technologies). Three independent transfection experiments were performed.

Coimmunoprecipitation assay. Coimmunoprecipitation was performed as described previously (Tao et al., 2003; Park et al., 2009). The DRGs from WT and $M b d 1^{-1-}$ mice were collected in the lysis buffer containing $50 \mathrm{mmol}$ Tris, $\mathrm{pH} 8.0,150 \mathrm{mmol} \mathrm{NaCl}, 0.1 \%$ SDS, $1.0 \%$ NP-40, protease inhibitor mixture, and $10 \mu \mathrm{M}$ TSA and homogenized with glass tissue grinders. After the centrifugation, the supernatant was collected and then preincubated with $50 \mu \mathrm{l}$ protein $\mathrm{A} / \mathrm{G}$ mouse agarose (Santa Cruz Biotechnology). After overnight incubation, $400 \mu \mathrm{g}$ proteins were used to incubate with rabbit anti-DNMT3a serum (Ab13888, Abcam) plus Protein A/G mouse Agarose (Santa Cruz Biotechnology) by rotation for $4 \mathrm{~h}$ at $4^{\circ} \mathrm{C}$. After the mixture was washed four times with the lysis buffer, the proteins were eluted by boiling loading buffer before being loaded onto an SDS-polyacrylamide gel (Bio-Rad) and transferred to a PVDF membrane (Bio-Rad) followed by Western blot analysis. MBD1 and DNMT3a were detected as described above.
Whole-cell patch-clamp recording. The acute disassociated DRG neurons from adult WT and $M b d 1^{-1-}$ mice were cultured as described above. Whole-cell voltage-clamped recording as described previously (Liang et al., 2016a; J. Y. Zhao et al., 2017) was performed $4-10 \mathrm{~h}$ after plating. The micropipettes' electrode resistances ranged from 3 to $5 \mathrm{M} \Omega$. The neurons were voltage-clamped with an Axopatch-700B amplifier (Molecular Devices). The intracellular pipette solution consisted of the following (in $\mathrm{mM}$ ): potassium gluconate $120, \mathrm{KCl} 20, \mathrm{MgCl}_{2} 2$, EGTA 10 , HEPES 10, and Mg-ATP 4, pH 7.3 (with KOH, 310 mOsm). To diminish the $\mathrm{Na}^{+}$and $\mathrm{Ca}^{2+}$ component in voltage-gated potassium current, an extracellular solution contained the following (in $\mathrm{mM}$ ): choline chloride $150, \mathrm{KCl} 5, \mathrm{CdCl}_{2} 1, \mathrm{CaCl}_{2} 2, \mathrm{MgCl}_{2} 1$, HEPES 10, and glucose 10, $\mathrm{pH} 7.4$ (with Tris base, $320 \mathrm{mOsm}$ ). Signals were filtered at $1 \mathrm{kHz}$ and digitized using a DigiData 1550 with pClamp 10.4 software (Molecular Devices). Series resistance was compensated by $60 \%-80 \%$. Cell membrane capacitances were acquired by reading the value for whole-cell capacitance compensation directly from the amplifier. An online P/4 leak subtraction was performed to eliminate leak current contribution. The data were stored on computer by a DigiData 1550 interface and were analyzed by the pCLAMP 10.4 software package (Molecular Devices).

The action potential (AP) was also recorded with the use of whole-cell current clamp. The coverslips were placed in the chamber and perfused with extracellular solution consisting of the following (in mM): $\mathrm{NaCl} 140$, $\mathrm{KCl} 4, \mathrm{CaCl}_{2} 2, \mathrm{MgCl}_{2}$ 2, HEPES 10, and glucose 5, with $\mathrm{pH}$ adjusted to 7.38 by $\mathrm{NaOH}$. The intracellular pipette solution contained the following (in mM): $\mathrm{KCl} 135, \mathrm{Mg}$-ATP 3, $\mathrm{Na}_{2} \mathrm{ATP} 0.5, \mathrm{CaCl}_{2}$ 1.1, EGTA 2, and glucose 5; $\mathrm{pH}$ was adjusted to 7.38 with $\mathrm{KOH}$ and osmolality adjusted to $300 \mathrm{mOsm}$ with sucrose. The resting membrane potential was taken 3 min after a stable recording was first obtained. To evoke AP, we delivered depolarizing currents from 100 to $1400 \mathrm{pA}$ (100 pA increment, $200 \mathrm{~ms}$ duration). The AP threshold was defined as the first point on the rapid rising phase of the spike at which the change in voltage exceeded 50 $\mathrm{mV} / \mathrm{ms}$. The membrane potential was held at the existing resting membrane potential during the current injection. The AP amplitude was measured between the peak and the baseline, and the AP overshoot was measured between the AP peak and $0 \mathrm{mV}$. To measure the membrane input resistance, each cell was delivered with a series of hyperpolarizing currents, $200 \mathrm{~ms}$ duration delivered in steps of $100 \mathrm{pA}$ from $200 \mathrm{pA}$ to $2000 \mathrm{pA}$, and the membrane input resistance was obtained from the slope of a steady-state $I-V$ plot. The after-hyperpolarization amplitude was measured between the maximum hyperpolarization and the final plateau voltage. The data were stored on computer by a DigiData 1500 interface and were analyzed by the pCLAMP 10.4 software package (Molecular Devices). All experiments were performed at room temperature.

Calcium image. Intracellular $\mathrm{KCl}$-induced $\left[\mathrm{Ca}^{2+}\right] i$ transients via voltage-dependent $\mathrm{Ca}^{2+}$ channels in the DRG neurons were measured with TILLvisION Imaging System version 3.3 (T.I.L.L. Photonics) as described previously (Vetter et al., 2006; Thyagarajan et al., 2009; Han et al., 2013; Lukacs et al., 2013). Acute disassociated DRG cultured neurons from WT and $M b d 1^{-1-}$ mice were prepared as described above. Three days after plating, the neurons were washed to remove the serum and then loaded with $2 \mu \mathrm{M}$ fura-2 AM (Invitrogen) for $30 \mathrm{~min}$ in the dark at room temperature. After washing, the neurons were placed in a recording chamber mounted on an inverted IX51 microscope (Olympus) coupled to a dual excitation $\mathrm{Ca}^{2+}$ imaging system (Photon Technology International). $\mathrm{Ca}^{2+}$ responses were induced by the application of 100 mM KCl (osmotically corrected by reducing the $\mathrm{Na}^{+}$concentration) with or without $200 \mu \mathrm{M}$ DAMGO/400 $\mu \mathrm{M}$ D-Phe-Cys-Tyr-D-Trp-Orn-ThrPen-Thr-NH2 (CTOP) and imaged at 340 and $380 \mathrm{~nm}$ excitation wavelengths to detect intracellular free calcium. CTOP was given $5 \mathrm{~min}$ before $\mathrm{DAMGO} / \mathrm{KCl}$ application. The experiments were performed in triplicate and repeated with at least 3 separate batches of culture.

cAMP assay. cAMP was measured by using a radioimmune assay kit (GE Healthcare) as described by the manufacturer (Vetter et al., 2006; Udina et al., 2010). Acute disassociated DRG cultured neurons from WT and $\mathrm{Mbd1}^{-1-}$ mice were prepared in 6-well plates as described above. Three days after plating, the neurons were stimulated with or without DAGMO (160 nM) or coadministration with CTOP (400 nM) in the presence or absence of $50 \mu \mathrm{M}$ forskolin (FSK, catalog \#1099, Tocris Bio- 

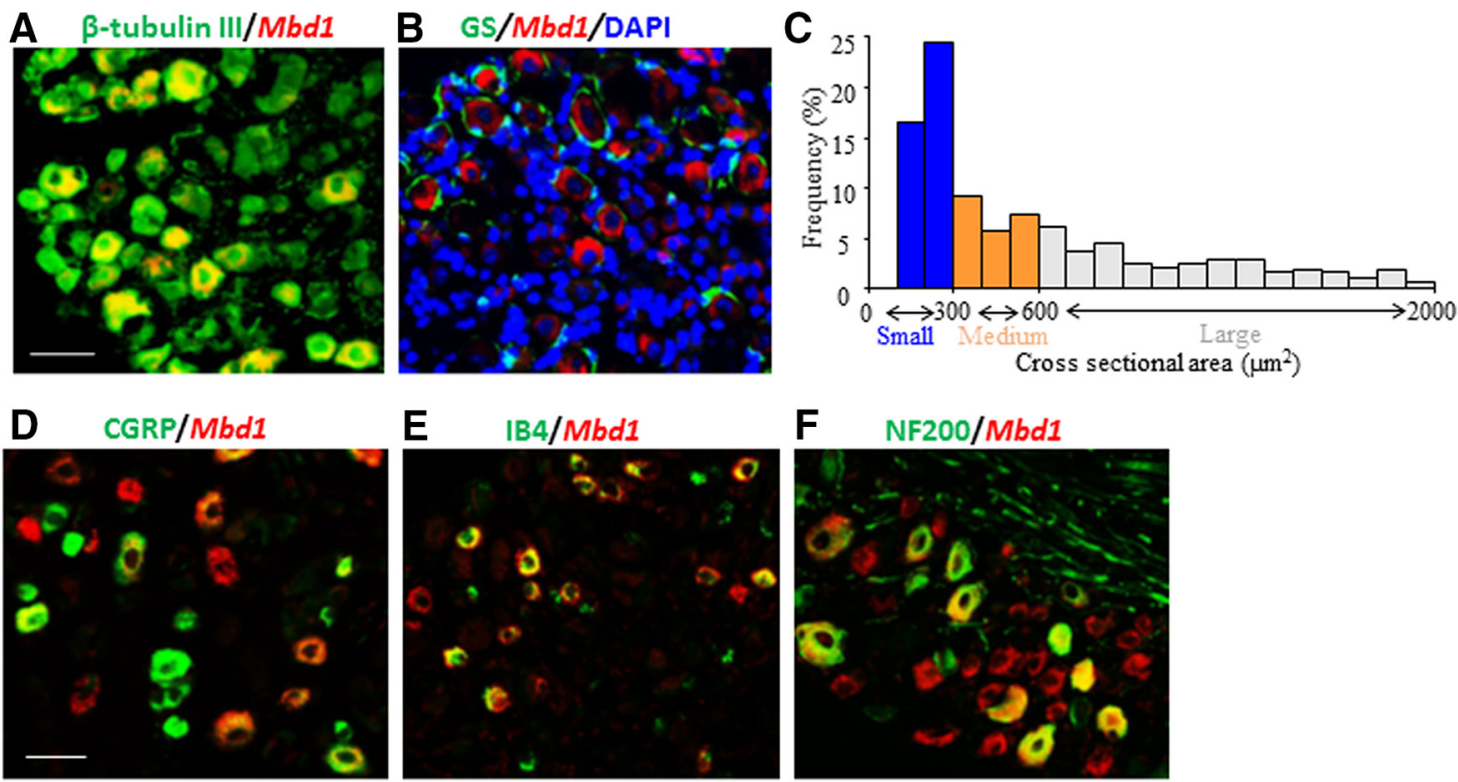

Figure 1. Distribution of Mbd1 mRNA in the DRG. $A, B$, Double labeling of Mbd1 mRNA ISH histochemistry (red) with immunohistochemistry of DRG cell markers, $\beta$-tubulin III and GS (green; $A, B$ ). B, Counterstaining with DAPI (blue). $n=3$ mice. Scale bar, $45 \mu \mathrm{m}$. C, Distribution of Mbd1 mRNA-labeled neuronal somata. Small, $40.9 \%$; medium, $22.5 \%$; large, 36.6\%. D-F, Double labeling of Mbd1 mRNA ISH histochemistry (red) with immunohistochemistry of (GRP ( green; $\boldsymbol{D}$ ), IB4 (green; $\boldsymbol{E}$ ), and NF200 (green; $\boldsymbol{F}$ ). $n=3$ mice. Scale bar, $45 \mu \mathrm{m}$. Validation of the Mbd1 antisense probe is shown in Figure 1-1, available at https://doi.org/10.1523/JNEUROSCI.0880-18.2018.f1-1.

science, an adenylyl cyclase activator). CTOP was given 5 min before DAGMO for $15 \mathrm{~min}$. FSK was then added for another $15 \mathrm{~min}$. After incubation, reactions were terminated. Intracellular cAMP levels were measured with a competitive cAMP EIA kit in triplicate as per the manufacturer's instructions. The experiments were performed in triplicate and repeated with at least 3 separate batches of culture.

Statistical analysis. All data are presented as mean \pm SEM. The data were statistically analyzed with two-tailed, unpaired Student's $t$ test and a one-way or two-way ANOVA. When ANOVA showed significant difference, pairwise comparisons between means were tested by the post hoc Turkey method (Sigma-Aldrich, Plot 12.5). The cells were equally suspended and then randomly distributed in each tested well for the in vitro experiments. The mice were distributed into different treated groups randomly for the in vivo experiments. $p<0.05$ was considered statistically significant in all analyses.

\section{Results}

\section{Distribution of $M b d 1$ mRNA in the DRG}

We first examined the distribution pattern of DRG MBD1. Because the MBD1 antibody we used is not recommended for immunohistochemistry, we performed the ISH histochemistry of Mbd1 mRNA combined with immunohistochemistry of DRG different markers. The $M b d 1$ mRNA was located predominantly in cytoplasm (Fig. 1A; Fig. 1-1, available at https://doi.org/ 10.1523/JNEUROSCI.0880-18.2018.f1-1) and coexpressed with $\beta$-tubulin III (a specific neuronal marker), but not GS (a marker for satellite glial cells) in the DRG (Fig. 1A,B), indicating that MBD1 is expressed exclusively in DRG neurons. Approximately $61.6 \%$ (607 of 985) of $\beta$-tubulin III-positive neurons were labeled for Mbd1 mRNA in the DRG of the WT mice. As expected, no Mbd1 mRNA signals were detected in the DRG from the $M b d 1^{-1-}$ mice (Fig. 1-1, available at https://doi.org/10.1523/ JNEUROSCI.0880-18.2018.f1-1). Moreover, a cross-sectional area analysis of neuronal somata displayed that $\sim 36.6 \%$ of $M b d 1$ mRNA-labeled neurons were large ( $>600 \mu \mathrm{m}^{2}$ in area; Fig. 1C), $22.5 \%$ were medium (300-600 $\mu \mathrm{m}^{2}$ in area; Fig. $1 C$ ), and $40.9 \%$ were small $\left(<300 \mu \mathrm{m}^{2}\right.$ in area; Fig. 1C). Consistently, subpopulation analysis revealed that $\sim 34.2 \%$ of $M b d 1$ mRNA-labeled neurons were positive for CGRP (a marker for small peptidergic neurons; Fig. 1D), 42.9\% for isolectin B4 (IB4, a marker for small nonpeptidergic neurons; Fig. $1 E$ ), and $33.3 \%$ for neurofilament200 (NF200, a marker for medium/large cells and myelinated $\mathrm{A} \beta$-fibers; Fig. $1 F)$.

\section{DRG MBD1 is required for maintaining acute pain}

To study the role of MBD1 in acute pain, we assessed basal mechanical, heat, and cold sensation in the $\mathrm{Mbd1}^{-1-}$ mice. Compared with the WT control littermates, $M b d 1^{-1-}$ mice, in the absence of tissue or nerve injury, exhibited a marked reduction in PWF to mechanical stimulation (Fig. 2A) and a significant increase in PWL to heat (Fig. 2B) or cold (Fig. 2C) stimulation and in tail flick latency to heat stimulation (Fig. 2D). Moreover, we subjected mice to capsaicin, a chemical stimulation, and observed capsaicin-induced acute nociceptive pain characterized by shaking/flinching and licking/lifting of injected hindpaw (Fan et al., 2014). Mbd1 ${ }^{-1-}$ mice showed significant reductions in the number of shaking/flinching (Fig. $2 E$ ) and in duration of licking/lifting (Fig. 2-1 A, available at https://doi.org/10.1523/ JNEUROSCI.0880-18.2018.f2-1) compared with the WT mice. Additionally, capsaicin-induced mechanical allodynia and heat hyperalgesia were blunted on the ipsilateral side of the $\mathrm{Mbd1}^{-/-}$ mice (Fig. 2-1B,C, available at https://doi.org/10.1523/ JNEUROSCI.0880-18.2018.f2-1). To further examine the role of DRG MBD1 in acute pain, we transiently knocked down DRG MBD1 expression through microinjection of Mbd1 siRNA into unilateral L3/4 DRG. NC siRNA was used as a control. Four days after microinjection, the level of DRG MBD1 in the Mbd1 siRNAtreated mice was reduced by $45 \%$ of the value of the NC siRNAtreated mice (Fig. 2-1D, available at https://doi.org/10.1523/ JNEUROSCI.0880-18.2018.f2-1). Like the $\mathrm{Mbd1}^{-1-}$ mice, the Mbd1-siRNA-treated mice, but not the NC siRNA-treated mice, revealed a substantial decrease in PWF to mechanical stimulation and a marked increase in PWL to heat or cold stimulation on the ipsilateral (not contralateral) side (Fig. 2F; Fig. 2-1E, available at 

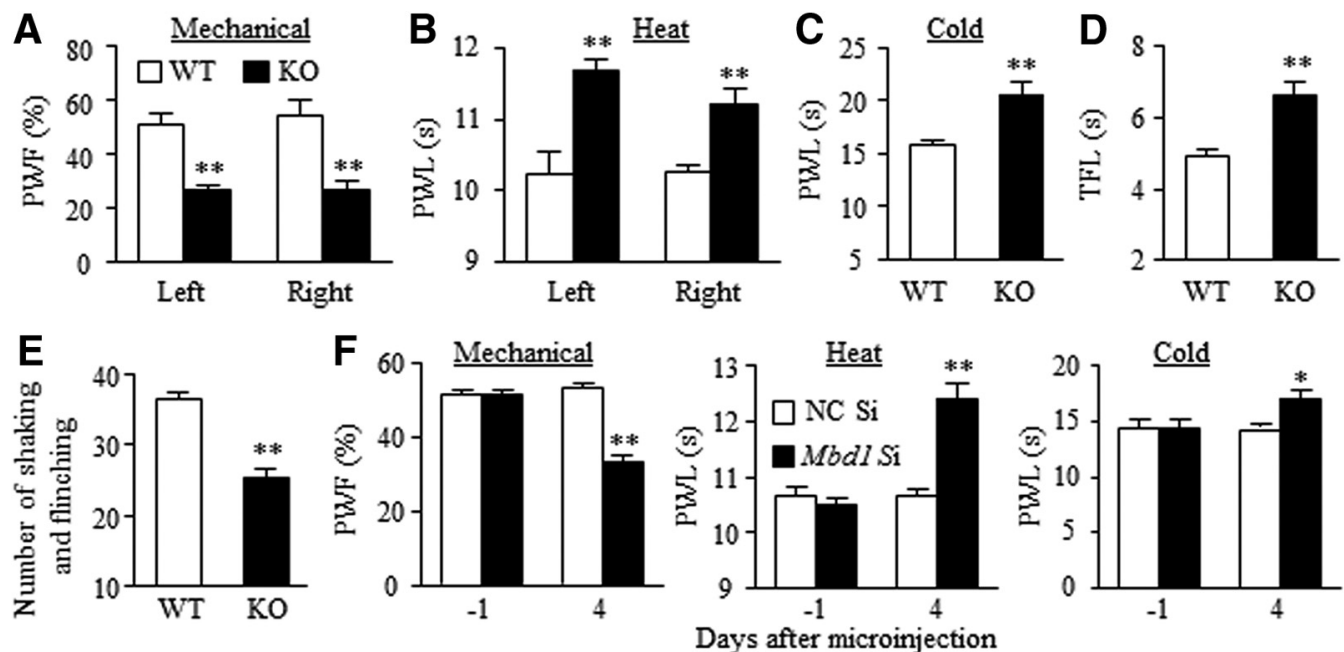

Figure 2. DRG MBD1 is required for maintaining acute pain. TFL, Tail flick latency. $\boldsymbol{A}-\boldsymbol{D}$, Effect of MBD1 K0 on basal paw withdrawal responses to mechanical $(\boldsymbol{A})$, heat $(\boldsymbol{B})$, and cold $(\boldsymbol{C})$ stimuli and on basal tail flick response to heat stimulation (D). K0, $M b d 1^{-1-}$ mice. $n=7$ mice/group. Two-way ANOVA followed by posthoc Tukey test: $F_{\text {group }(1,27)}=43.69$ for $A$ and $F_{\text {group }(1,27)}=32.44$ for $\boldsymbol{B}$. Two-tailed unpaired Student's $t$ test for $\boldsymbol{C}(t=-3.14)$ and $\boldsymbol{D}(t=-4.07) .{ }^{* *} p<0.01$ versus the corresponding WT mice. $\boldsymbol{E}$, Effect of MBD1 K0 on capsaicin-induced pain behaviors as indicated by shaking and flicking. $n=6$ mice/group. ${ }^{* *} p<0.01$ versus the corresponding WT group (two-tailed unpaired Student's $t$ test) $(t=7.302)$. $F$, Effect of DRG MBD1 knockdown through microinjection of MBD1 small interfering RNA (Mbd1 Si) into unilateral L3/4 DRGs on basal paw withdrawal responses to mechanical, heat, and cold stimuli on the ipsilateral side. NC Si, NC siRNA. $n=12$ mice/group. Two-way ANOVA followed by post hoc Tukey test: $F_{\text {group }(1,47)}=60.92$ for mechanical, $F_{\text {group }(1,47)}=21.11$ for heat, and $F_{\text {group }(1,47)}=74.03$ for cold. ${ }^{*} p<0.05$ versus the NC Si-treated group at the corresponding time point. ${ }^{*} p<0.01$ versus the NC Si-treated group at the corresponding time point. Effect of DRG MBD1 deficiency on acute pain is shown in Figure 2-1, available at https://doi.org/10.1523/JNEUROSCI.0880-18.2018.f2-1.

Table 2. Locomotor functions ${ }^{a}$

\begin{tabular}{llll}
\hline & \multicolumn{2}{l}{ Functional test } \\
\cline { 2 - 4 } Treatments/genotyping & Placing & Grasping & Righting \\
\hline WT & $5(0)$ & $5(0)$ & $5(0)$ \\
K0 & $5(0)$ & $5(0)$ & $5(0)$ \\
NCSi & $5(0)$ & $5(0)$ & $5(0)$ \\
Mbd1 Si & $5(0)$ & $5(0)$ & $5(0)$ \\
AAV5-Gfp & $5(0)$ & $5(0)$ & $5(0)$ \\
AAV5-Mbd1 & $5(0)$ & $5(0)$ & $5(0)$ \\
AAV5-Gfp in WT & $5(0)$ & $5(0)$ & $5(0)$ \\
AAV5-Gfp in K0 & $5(0)$ & $5(0)$ & $5(0)$ \\
AAV5-Mbd1 in K0 & $5(0)$ & $5(0)$ & $5(0)$ \\
Vehicle + Sham & $5(0)$ & $5(0)$ & $5(0)$ \\
Vehicle + SNL & $5(0)$ & $5(0)$ & $5(0)$ \\
NCSi + SNL & $5(0)$ & $5(0)$ & $5(0)$ \\
Mbd1 Si + Sham & $5(0)$ & $5(0)$ & $5(0)$ \\
Mbd1 Si + SNL & $5(0)$ & $5(0)$ & $5(0)$ \\
\hline
\end{tabular}

${ }^{a}$ Values are mean (SEM). $n=5$ mice/group; 5 trials. NC Si, Negative control small interference RNA.

https://doi.org/10.1523/JNEUROSCI.0880-18.2018.f2-1). Both $\mathrm{Mbd1}^{-1-}$ mice and siRNA-treated mice displayed normal locomotor functions (X. Zhao et al., 2003) (Table 2). Collectively, DRG MBD1 is required for maintaining normal transmission of normal sensory and acute noxious information.

\section{DRG MBD1 is required for development and maintenance of neuropathic pain}

We also examined the role of MBD1 in neuropathic pain. We used an established mouse model of the L4 SNL-induced neuropathic pain. Consistent with previous reports (Liang et al., 2016a; Li et al., 2017), SNL led to long-term mechanical allodynia, heat hyperalgesia, and cold allodynia on the ipsilateral side of the WT mice. In the $M b d 1^{-1-}$ mice, basal sensitivities in response to mechanical, heat, and cold stimuli were lower on both sides as observed under acute pain conditions above. The amplitudes of mechanical allodynia, heat hyperalgesia, and cold allodynia were significantly reduced on the ipsilateral side of the $M b d 1^{-1-}$ mice after SNL (Fig. 3A-C). As expected, basal responses were not changed on the contralateral side after SNL (Fig. 3A-C) or on both sides after sham surgery (data not shown). SNL or sham mice exhibited intact locomotor functions (Table 2). Additionally, we performed the mouse model of inflammatory pain caused by intraplantar injection of formalin or CFA (C. S. Zhao et al., 2003; Chu et al., 2005) and observed that, as in the SNL model, the $M b d 1^{-1-}$ mice displayed blunted CFA-induced pain hypersensitivities and formalin-induced pain behaviors during the observation periods (Fig. 3-1A, available at https://doi.org/10. 1523/JNEUROSCI.0880-18.2018.f3-1).

To exclude the possibility that the effects observed above in the $M b d 1^{-1-}$ mice were attributed to the developmental defects and loss of sensory neurons, we examined the morphology of DRG from the $M b d 1^{-1-}$ mice. Cresyl violet staining showed that DRG cells, including neurons and satellite cells from the $M b d 1^{-1-}$ mice, did not have any abnormal changes compared with the WT mice (Fig. 3-2A, available at https://doi.org/ 10.1523/JNEUROSCI.0880-18.2018.f3-2). Cell architecture appeared normal (Fig. 3-2 A, available at https://doi.org/10.1523/ JNEUROSCI.0880-18.2018.f3-2). No significant differences were seen in number of stained cells from the DRG between the WT and $M b d 1^{-1-}$ mice (Fig. 3-2A, available at https://doi.org/ 10.1523/JNEUROSCI.0880-18.2018.f3-2). Furthermore, numbers of CGRP-labeled neurons, IB4-labeled neurons, and NF200labeled neurons in the DRG of the $M b d 1^{-1-}$ mice are similar to those in the DRG of the WT mice (Fig. 3-2 B, available at https:// doi.org/10.1523/JNEUROSCI.0880-18.2018.f3-2). In addition, the localization and distribution of IB4-labeled and CRGPlabeled primary afferent terminals in spinal cord dorsal horn from the $M b d 1^{-1-}$ mice are normal compared with the WT mice (Fig. 3-2E,F, available at https://doi.org/10.1523/JNEUROSCI. 0880-18.2018.f3-2).

To further define whether DRG MBD1 had a functional role in neuropathic pain development, we microinjected siRNA into unilateral L4 DRG $4 \mathrm{~d}$ before SNL or sham surgery. Like the 

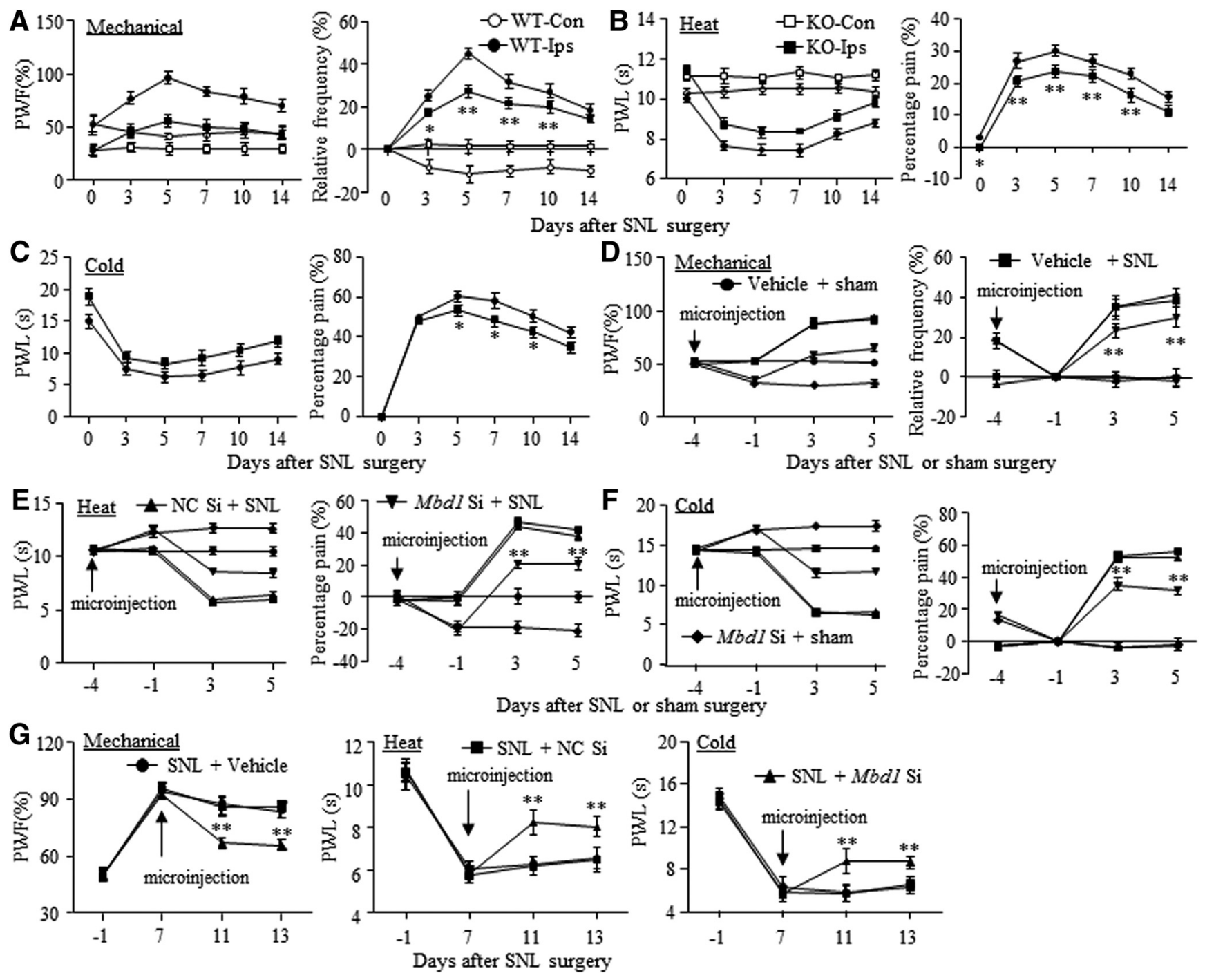

Figure 3. DRG MBD1 is required for development and maintenance of neuropathic pain. Raw values (left) and relative frequency (right: value post time point - value $_{\text {baseline (0 or }-1 \mathrm{~d})}$ ) or percentage pain (right: value contralateral $_{-}-$value $\left._{\text {ipsilateral }}\right) / v_{\text {alue }}$ contralateral) $\cdot A-C$, Effect of MBD1 KO on SNL-induced mechanical allodynia $(\boldsymbol{A})$, heat hyperalgesia (B), and cold allodynia (C). Con, Contralateral; Ips, ipsilateral; $K 0, M b d 1^{-1-}$ mice; $n=7$ mice/group. Two-way ANOVA followed by posthoc Tukey test: $F_{\text {group }(3,155)}=471.48$ for $\boldsymbol{A}$ (left) and $F_{\text {group }(3,155)}=234.97$ for $\boldsymbol{A}$ (right). $F_{\text {group }(3,132)}=495.58$ for $\boldsymbol{B}$ (left) and $F_{\text {group }(1,66)}=43.50$ for $\boldsymbol{B}$ (right). $F_{\text {group }(1,66)}=376.43$ for $\boldsymbol{C}\left(\right.$ left) and $F_{\text {group }(1,66)}=8.73$ for $\boldsymbol{C}$ (right). ${ }^{*} p<0.05$ versus WT mice on the contralateral side at the corresponding time point. ${ }^{* *} p<0.01$ versus WT mice on the contralateral side at the corresponding time point. $D-F$, Effect of premicroinjection of $M b d 1$ siRNA into the ipsilateral L3/4 DRGs on SNL-induced mechanical allodynia $(\boldsymbol{D})$, heat hyperalgesia $(\boldsymbol{E})$, and cold allodynia $(\boldsymbol{F})$ on the ipsilateral side. NC Si, NC siRNA. $n=6$ mice/group. Two-way ANOVA followed by post hoc Tukey test: $F_{\text {group }(4,119)}=140.07$ for $\boldsymbol{D}$ (left) and $F_{\text {group }(4,119)}=99.98$ for $\boldsymbol{D}$ (right). $F_{\text {group }(4,119)}=100.73$ for $\boldsymbol{E}$ (left) and $F_{\text {group }(4,119)}=102.58$ for $\boldsymbol{E}$ (right). $F_{\text {group }(4,119)}=269.19$ for $\boldsymbol{F}$ (left) and $F_{\text {group }(4,119)}=223.94$ for $\boldsymbol{F}$ (right). ${ }^{* *} p<$ 0.01 versus the vehicle plus sham group at the corresponding time point. $G$, Effect of post microinjection of Mbd1 siRNA into the ipsilateral L3/4 DRGs on SNL-induced mechanical allodynia, heat hyperalgesia, and cold allodynia on the ipsilateral side. $n=5-7$ mice/group. Two-way ANOVA followed by post hoc Tukey test: $F_{\text {group }(2,67)}=14.74$ for left, $F_{\text {group }(2,67)}=26.74$ for middle, and $F_{\text {group }(2,67)}=15.43$ for right. ${ }^{* *} p<0.01$ versus the vehicle plus SNL group at the corresponding time point. The role of DRG MBD1 in inflammatory pain is shown in Figure 3-1, available at https://doi.org/10.1523/JNEUROSCI.0880-18.2018.f3-1. No obvious changes in the DRG of the Mbd1 ${ }^{-1-}$ mice is shown in Figure 3-2, available at https://doi.org/10.1523/JNEUROSCI.088018.2018.f3-2. Effect of DRG MBD1 knockdown on the behavioral responses on the contralateral side is shown in Figure 3-3, available at https://doi.org/10.1523/JNEUROSCI.0880-18.2018.f3-3.

$\mathrm{Mbd1}^{-1-}$ mice, the Mbd1-siRNA-treated mice, but not the NC siRNA-treated mice, displayed lower mechanical, heat, and cold sensitivities $1 \mathrm{~d}$ before surgery and impaired mechanical allodynia, heat hyperalgesia, and cold allodynia on days 3 and 5 after SNL on the ipsilateral side compared with the vehicle-injected SNL mice (Fig. 3D-F). As expected, DRG microinjection of $M b d 1$-siRNA lowed basal mechanical, heat, and cold sensitivities on the ipsilateral side of sham mice (Fig. $3 D-F$ ). We also observed the role of DRG MBD1 in neuropathic pain maintenance through microinjection of siRNA into unilateral L4 DRG $7 \mathrm{~d}$ after SNL. Consistently, blunted mechanical allodynia, heat hyperalgesia, and cold allodynia were seen on days 11 and 13 after SNL on the ipsilateral side of the Mbd1-siRNA-treated mice, but not of the NC siRNA-treated mice (Fig. $3 G$ ). Neither siRNA changed basal responses on the contralateral side (Fig. 3-3A, B, available at https://doi.org/10.1523/JNEUROSCI.0880-18.2018.f3-3) and locomotor functions (Table 2) after surgery. Together, these findings suggest that DRG MBD1 is critical for neuropathic pain development and maintenance.

DRG overexpression of MBD1 leads to pain hypersensitivity Next, we asked whether DRG overexpression of MBD1 altered basal nociceptive thresholds in naive mice. To this end, we microinjected AAV5 that expressed full-length Mbd1 (AAV5$M b d 1$ ) into unilateral L3 and L4 DRG of naive adult mice. AAV5GFP was used as a control. As expected, a significant increase in 

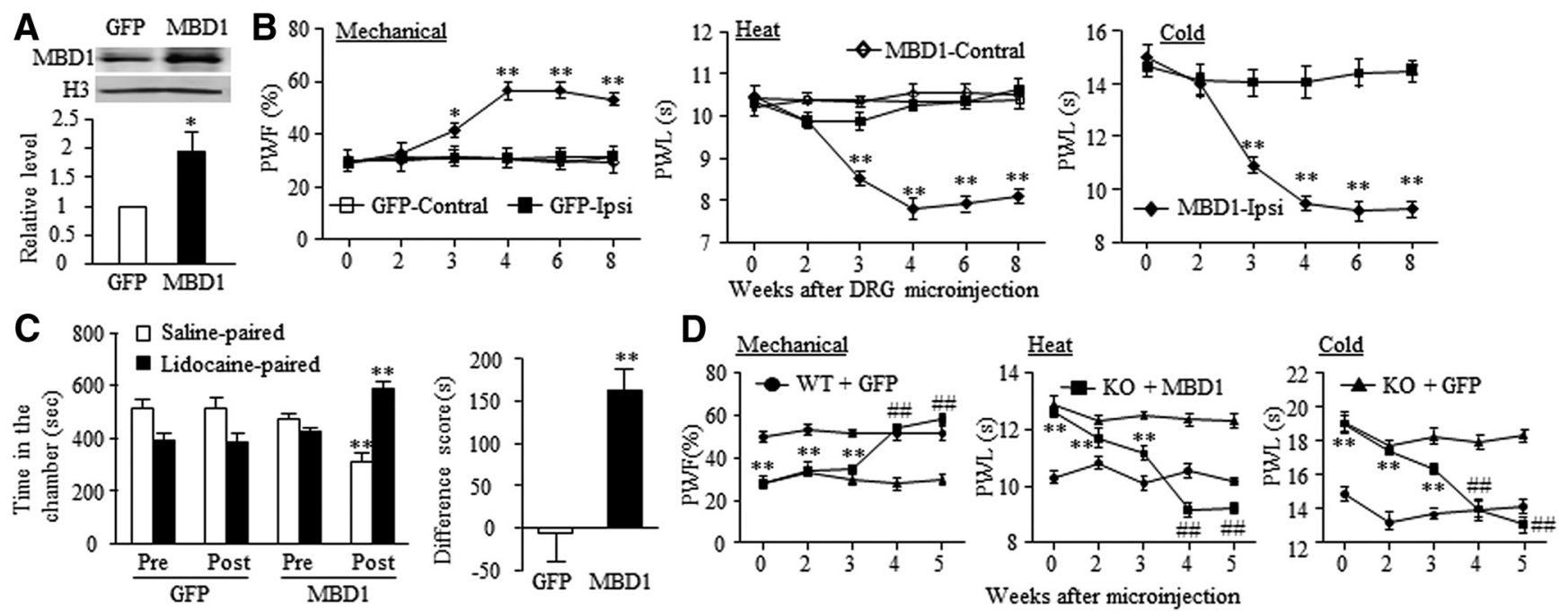

Figure 4. DRG overexpression of MBD1 leads to pain hypersensitivity in WT mice and rescues pain sensitivity in the Mbd1 ${ }^{-1-}$ mice. MBD1, AAV5-Mbd1; GFP, AAV5-GFP.A, An increase in MBD1 protein expression in the ipsilateral L3/4 DRGs 8 weeks after microinjection of AAV5-Mbd1 into these DRGs. $t=-2.78$. ${ }^{*} p<0.05$ versus the AAV5-GFP control group (two-tailed unpaired Student's $t$ test). $\boldsymbol{B}$, Microinjection of AAV5-Mbd1 into unilateral L3/4 DRGs produced mechanical allodynia, heat hyperalgesia, and cold allodynia on the ipsilateral (Ipsi) side of naive mice. Contral, Contralateral. $n=12$ mice per group. Two-way ANOVA followed by post hoc Tukey test: $F_{\text {group }(3,264)}=116.48$ for left, $F_{\text {group }(3,264)}=429.15$ for middle, and $F_{\text {group }(1,132)}=754.92$ for right. ${ }^{*} p<$ 0.05 versus the AAV5-GFP group at the corresponding time point. ${ }^{* *} p<0.01$ versus the AAV5-GFP group at the corresponding time point. C, Microinjection of AAV5-Mbd 1 into unilateral L3/4 DRGs produced spontaneous ongoing pain as assessed by conditioned place preference assay. $n=12$ mice/group. Two-way ANOVA followed by posthoc Tukey test: $F_{\text {group }(3,95)}=0.52$ for left $\left({ }^{* *} p<0.01\right.$ vs the corresponding preconditioning) and $t=-3.97$ for right ${ }^{* *} p<0.01$ vs the AAV5- GFP group by two-tailed, independent Student's $t$ test). D, Like WT mice, Mbd1 ${ }^{-1-}$ (KO) mice microinjected with AAV5-Mbd1 into unilateral L3/4 DRGs displayed intact responses to mechanical, heat, and cold stimuli on the ipsilateral side. $n=6-10$ mice/group. Two-way ANOVA followed by post hoc Tukey test: $F_{\text {group }(2,109)}=95.01$ for left, $F_{\text {group }(2,109)}=85.56$ for middle, and $F_{\text {group }(2,109)}=248.87$ for right. ${ }^{* *} p<0.01$ versus the AAV5-GFP-injected WT group at the corresponding time point. ${ }^{\# \#} p<0.01$ versus the AAV5-GFP-injected K0 group at the corresponding time point. Effect of MBD1 overexpression in unilateral L3/4 DRGs of the Mbd1 ${ }^{-1-}$ mice on the behavioral responses on the contralateral side is shown in Figure 4-1, available at https://doi.org/10.1523/JNEUROSCI.0880-18.2018.f4-1.

the level of MBD1 was detected in the injected DRG 8 weeks after microinjection of AAV5-Mbd1 compared with microinjection of AAV5-GFP (Fig. 4A). Microinjection of AAV5-Mbd1, but not AAV5-GFP, led to mechanical allodynia, heat hyperalgesia, and cold allodynia as demonstrated by ipsilateral increase in PWF to mechanical stimulation and by ipsilateral decreases in PWLs to heat and cold stimuli (Fig. 4B). These pain hypersensitivities appeared between 3 and 4 weeks and persisted for at least 8 weeks (Fig. $4 B$ ), consistent with the 3 to 4 week lag period for AAV5 expression, which lasts for at least 3 months (X. Zhao et al., 2013; Li et al., 2015). There were no changes in basal paw responses on the contralateral side (Fig. 4B) and locomotor functions (Table 2) after either viral microinjection. Additionally, we used a conditional place preference paradigm and showed that the mice microinjected with AAV5-Mbd1, but not AAV5-GFP, spent more time for the lidocaine-paired chamber (Fig. 4C), indicating stimulation-independent spontaneous pain. Our findings suggest that increased MBD1 in the DRG leads to both spontaneous and evoked pain hypersensitivities.

To determine whether blunted acute pain sensitivities in the $M b d 1^{-1-}$ mice were attributed to DRG MBD1 deficiency, we overexpressed MBD1 in the DRG of the $M b d 1^{-1-}$ mice through microinjection of AAV5-Mbd1 into unilateral L3 and L4 DRGs. As observed in the $M b d 1^{-1-}$ mice above, the AAV5-GFPmicroijnected $M b d 1^{-1-}$ mice exhibited insensitive responses to acute mechanical, heat, and cold stimuli compared with the AAV5-GFP-microinjected WT mice on the ipsilateral side (Fig. $4 D)$. However, the $M b d 1^{-1-}$ mice microinjected with AAV5Mbd1 restored acute mechanical, heat, and cold sensitivities as evidenced by similar paw withdrawal responses to mechanical, heat, and cold stimuli between the AAV5-Mbd1-microinjected $M b d 1^{-1-}$ mice and the AAV5-GFP-microinjected WT mice 4 and 5 weeks after microinjection on the ipsilateral (but not con- tralateral) side (Fig. 4D; Fig. 4-1, available at https://doi.org/ 10.1523/JNEUROSCI.0880-18.2018.f4-1). As expected, viral microinjection in both mice did not alter locomotor function (Table 2). The evidence indicates that DRG MBD1 deficiency may be responsible for reduced acute pain sensitivities in the $M b d 1^{-1-}$ mice.

\section{MBD1 negatively regulates Oprm1 and Kcna2 expression in DRG neurons}

How does DRG MBD1 deficiency affect acute pain sensitivities and neuropathic pain genesis? Opioid receptors and voltagegated potassium channels control the excitability of DRG neurons and neurotransmitter release of primary afferents (Pohl et al., 1989; Collin et al., 1993; Taddese et al., 1995; Heinke et al., 2011; X. Zhao et al., 2013; Fan et al., 2014; Li et al., 2015, 2017; Liang et al., 2016a; J. Y. Zhao et al., 2017). We found that the levels of Oprm1 (encoding MOR), Oprk1 (encoding KOR), and Kcna2 (encoding Kv1.2) mRNAs, but not Oprd1 (encoding $\delta$ opioid receptor), Kcnal (encoding Kv1.1), and Kcna4 (encoding Kv1.4) mRNAs, were significantly increased in the DRG of the $M b d 1^{-1-}$ mice (Fig. 5A; Fig. 5-1A, available at https://doi.org/10.1523/ JNEUROSCI.0880-18.2018.f5-1). These increases were also seen in the spinal cord dorsal horn and cortex, but not in midbrain, of the $M b d 1^{-1-}$ mice (Fig. 5-1B, available at https://doi.org/ 10.1523/JNEUROSCI.0880-18.2018.f5-1). Unexpectedly, the amounts of MOR and Kv1.2 proteins (not KOR protein) were substantially elevated in the DRG, but not in spinal cord dorsal horn and cortex, of the $\mathrm{Mbd1}^{-1-}$ mice (Fig. 5B; Fig. 5-1E, F, available at https://doi.org/10.1523/JNEUROSCI.0880-18.2018. f5-1). The number and immunostaining density of MOR-labeled neurons from the $\mathrm{Mbd1}^{-1-}$ mouse DRG were greater than those from the WT mouse DRG (Fig. $5 C$ ). The number of Kv1.2labeled neurons from the $M b d 1^{-1-}$ mouse DRG was not signif- 

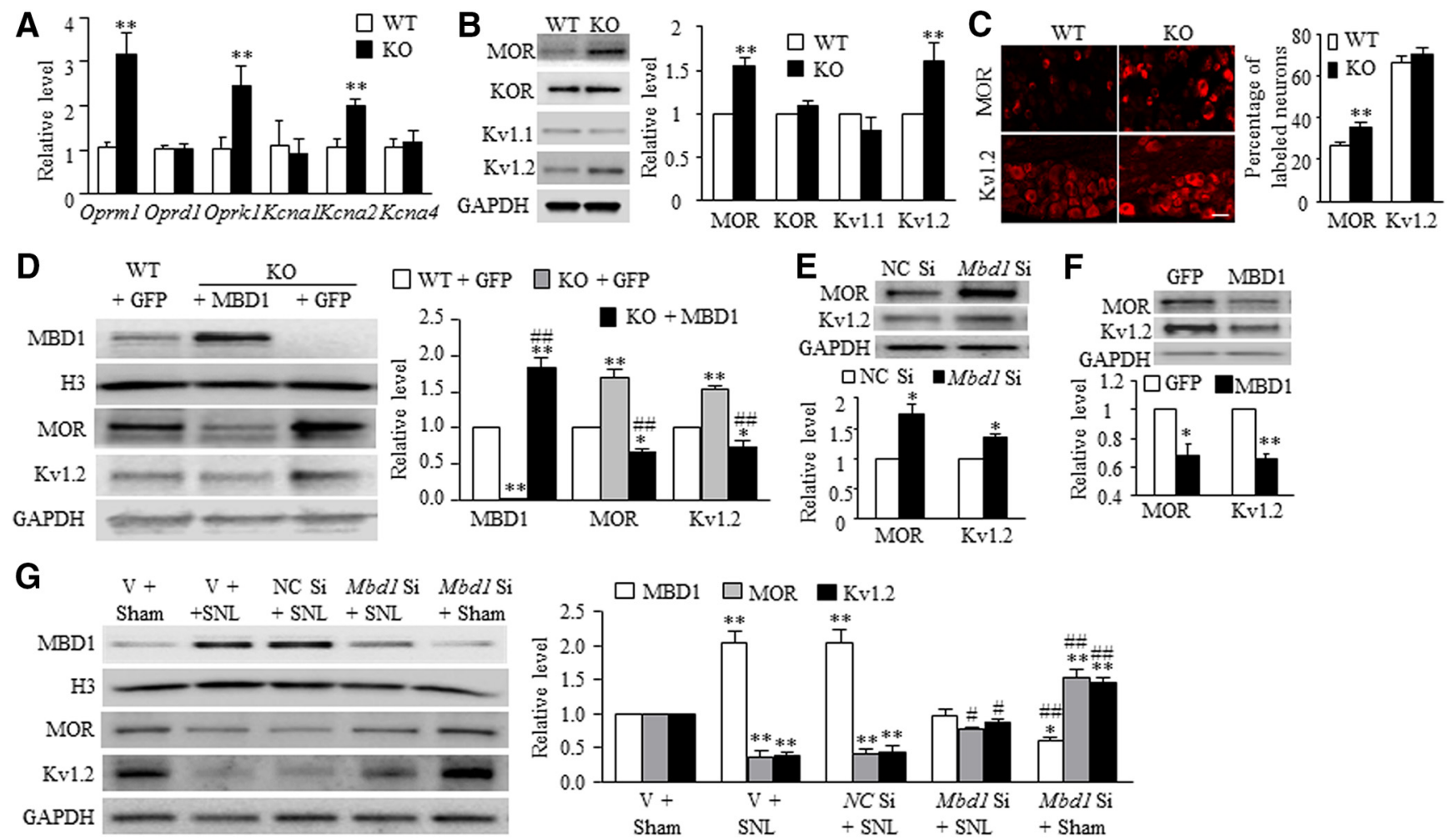

Figure 5. MBD1 negatively regulates Oprm 1 and Kcna2 expression in DRG neurons. K0, Mbd1 ${ }^{-1}-$ mice. $A$, Expression of Oprm 1, Oprk1, Oprd1, Kcna1, Kcna2, and Kcna $4 \mathrm{mRNAs}$ in the DRG from WT mice $(n=8)$ and $M b d 1^{-1}$ - mice $(n=7) . t=-4.557$ for Oprm1, $t=-7.406$ for Oprk1, and $t=-3.733$ for Kcna2. ${ }^{* *} p<0.01$ versus the corresponding WT mice (two-tailed unpaired Student's $t$ test). $\boldsymbol{B}$, Expression of MOR, KOR, Kv1.1, and Kv1.2 proteins in the DRG from WT mice $(n=7)$ and Mbd ${ }^{-1-}$ mice $(n=5)$. Representative Western blots (left panels) and summary of densitometric analysis (right graphs). $t=-16.27$ for MOR and $t=28.00$ for Kv1.2. ${ }^{* *} p<0.01$ versus the corresponding WT mice (two-tailed unpaired Student's $t$ test). C, Representative immunohistochemical images (left) and a summary of analysis on the number of MOR- or Kv1.2-labeled neurons (right) from WT mice $(n=3)$ and Mbd1 $1^{-1-}$ mice $(n=3) . t=-3.32$ for MOR and $t=0.97$ for Kv1.2. ${ }^{* *} p<0.01$ versus the corresponding WT mice (two-tailed unpaired Student's $t$ test). Scale bar, $50 \mu \mathrm{m}$. D, Expression of MBD1, MOR, and Kv1.2 proteins in the ipsilateral L3/4 DRGs from the WT or Mbd1 ${ }^{-1}$ - mice with microinjection of AAV5-GFP (GFP) or AAV5-Mbd1 (MBD1) into these DRGs. Representative Western blots (left panels) and a summary of densitometric analysis (right graphs). $n=3$ repeats (from 6 mice/group). One-way ANOVA followed by post hoc Tukey test: $F_{\text {group }(2,8)}=122.57$ for MBD1, $F_{\text {group }(2,8)}=48.79$ for $M O R$, and $F_{\text {group }(2,8)}=81.95$ for Kv1.2. ${ }^{*} p<0.05$ versus the AAV5-GFP-injected mice. ${ }^{* *} p<0.01$ versus the AAV5-GFP-injected mice. ${ }^{\# \#} p<0.01$ versus the AAV5-GFP-injected Mbd1 ${ }^{-1-}$ mice. E, Expression of MOR and Kv1.2 proteins in the ipsilateral L3/4 DRGs 4 d after microinjection of Mbd1 siRNA (Mbd1 Si) or NC siRNA (NCSi) into these DRGs from naive mice. $n=6$ mice/group, 3 repeats. $t=-4.61$ for MOR and $t=$ -4.92 for Kv1.2. ${ }^{*} p<0.05$ versus the corresponding NC siRNA-injected group (two-tailed unpaired Student's $t$ test). $F$, Expression of MOR and Kv1.2 proteins in the ipsilateral L3/4 DRGs 8 weeks after microinjection of AAV5-Mbd1 (MBD1) or AAV5-GFP (GFP) into these DRGs from naive mice. $n=12$ mice/group. $t=9.07$ for MOR and $t=13.78$ for Kv1.2. ${ }^{*} p<0.05$ versus the corresponding AAV5-GFP-injected group (two-tailed unpaired Student's $t$ test). ${ }^{* *} p<0.01$ versus the corresponding AAV5-GFP-injected group (two-tailed unpaired Student's $t$ test). G, Expression of MBD1, MOR, and Kv1.2 proteins in the ipsilateral L4 DRG from mice with microinjection of vehicle (V), Mbd1 siRNA (Mbd1 Si), or NC siRNA (NCSi) into this DRG 5 d after sham or SNL surgery. Representative Western blots (left panels) and a summary of densitometric analysis (right graphs). $n=12$ mice/group. One-way ANOVA followed by post hoc Tukey test: $F_{\text {group }(4,14)}=27.28$ for MBD1, $F_{\text {group }(4,14)}=38.35$ for MOR, and $F_{\text {group(4,14) }}=46.78$ for Kv1.2. ${ }^{*} p<0.05$ versus the corresponding vehicle plus sham group. ${ }^{* *} p<0.01$ versus the corresponding vehicle plus sham group. ${ }^{\#} p<0.05$ versus the corresponding vehicle plus SNL group. ${ }^{\#} p<0.01$ versus the corresponding vehicle plus SNL group. Expression of MOR and Kv1.2 regulated by MBD1 in the DRG is shown in Figure 5-1, available at https://doi.org/10.1523/JNEUROSCI.0880-18.2018.f5-1. Expressional change of DRG MBD1 after SNL is shown in Figure 5-2, available at https://doi.org/10.1523/JNEUROSCI.0880-18.2018.f5-2.

icantly altered compared with that from the WT mouse DRG (Fig. 5C), but the immunostaining densities of Kv1.2-labeled neurons from the $\mathrm{Mbd1}^{-1-}$ mouse DRG were much higher than that from the WT mouse DRG (Fig. 5-1G, available at https:// doi.org/10.1523/JNEUROSCI.0880-18.2018.f5-1). The increased expression of MOR and Kv1.2 in the $\mathrm{Mbd1}^{-1-}$ mouse DRG was absent after DRG overexpression of MBD1 through microinjection of AAV5-Mbd1 (not AAV5-GFP) into the DRG (Fig. 5D). Consistently, acute DRG MBD1 knockdown through DRG microinjection of $M b d 1$ siRNA also produced the marked increases in the levels of MOR and Kv1.2 proteins compared with DRG microinjection of NC siRNA (Fig. 5E). Furthermore, microinjection of AAV5-Mbd1 into WT mouse DRG largely decreased MOR and Kv1.2 expression (Fig. $5 F$ ). This in vivo observation was further confirmed by our in vitro experiment, in which transduction of AAV5-Mbd1 in cultured DRG neurons of WT mice reduced the levels of MOR and Kv1.2 proteins (Fig. 5-1 H, available at https://doi.org/10.1523/JNEUROSCI.0880-18.2018.f5-1).
These data suggest that DRG MBD1 deficiency impairs acute pain sensation likely through disinhibition of basal MOR and Kv1.2 expression in DRG.

In addition, we found that peripheral nerve injury timedependently upregulated the expression of MBD1 in the injured DRG, as shown by 2.54-, 2.22-, and 2.46-fold increases in the band densities in the ipsilateral (not contralateral) L4 DRG, respectively, on day 3, 7, and 14 after SNL (Fig. 5-2, available at https://doi.org/10.1523/JNEUROSCI.0880-18.2018.f5-2). Consistent with previous reports (X. Zhao et al., 2013; Fan et al., 2014; Li et al., 2015, 2017; Liang et al., 2016a,b; Sun et al., 2017; J. Y. Zhao et al., 2017), the vehicle-treated SNL mice displayed the decreases in the levels of MOR and Kv1.2 in the injured DRG on day 7 after SNL (Fig. 5G). These decreases could be rescued in the SNL mice with microinjection of Mbd1 SiRNA, but not NC siRNA, into the injured DRG (Fig. 5G). As expected, DRG microinjection of $M b d 1$ siRNA in the sham mice significantly increased basal expression of MOR and Kv1.2 in the injected DRG com- 
pared with the vehicle-treated sham mice (Fig. 5G). Given that nerve injury-induced downregulation of DRG MOR and Kv1.2 is an endogenous instigator of neuropathic pain (X. Zhao et al., 2013; Fan et al., 2014; Li et al., 2015; Liang et al., 2016b; Sun et al., 2017; J. Y. Zhao et al., 2017), our findings suggest that MBD1 contributes to neuropathic pain development and maintenance through its participation in nerve injury-induced MOR and Kv1.2 downregulation in the injured DRG.

\section{DRG MBD1 deficiency increases basal total $\mathrm{Kv}$ current and decreases basal excitability in DRG neurons}

We further inquired whether MBD1 deficiency would affect total $\mathrm{Kv}$ current in DRG neurons. Whole-cell voltage-clamp recording was performed and showed that total Kv current densities in large, medium, and small DRG neurons from the $\mathrm{Mbd1}^{-1-}$ mice significantly increased compared with those from the WT mice (Fig. 6A-I). To determine whether these increases were due to MBD1 deficiency-induced Kv1.2 upregulation, we applied 100 nM maurotoxin (MTX), a selective Kv1.2 current inhibitor (X. Zhao et al., 2013; Liang et al., 2016a; J. Y. Zhao et al., 2017) in bath. After MTX treatment, the reductions in total Kv currents in large and medium DRG neurons from the $\mathrm{Mbd1}^{-1-}$ mice were greater than those from the WT mice (Fig. $6 A-F$ ). When examined at $50 \mathrm{mV}$, total $\mathrm{Kv}$ currents in large and medium neurons from the $\mathrm{Mbd1}^{-1-}$ mice were reduced by $33.9 \%$ and $28.4 \%$, respectively, compared with those before MTX treatment, whereas total $\mathrm{Kv}$ currents in large and medium neurons from the WT mice were only reduced by $20.1 \%$ and $19.2 \%$, respectively, compared with those before MTX treatment (Fig. 6C,F). MTX did not affect total Kv currents in small DRG neurons from either WT or $M b d 1^{-1-}$ mice (Fig. 6G-I), which may be due to poor Kv1.2 expression in small DRG neurons (X. Zhao et al., 2013; Fan et al., 2014). These data reveal that DRG MBD1 deficiency increases total Kv currents in all DRG neurons and produces the increases in Kv1.2-related currents only in large and medium DRG neurons.

Whole-cell current-clamp recording was further used to assess DRG neuronal excitability. Basal resting membrane potentials in the $\mathrm{Mbd1}^{-1-}$ mice decreased by $6.7 \mathrm{mV}(p<0.01), 6.12$ $(p<0.01)$, and $6.4 \mathrm{mV}(p<0.01)$, respectively, in large, medium, and small neurons compared with those in the WT mice (Fig. $6 J$ ). Basal current thresholds in the $M b d 1^{-1-}$ mice increased by $25.1 \%(p<0.05), 66.9 \%(p<0.05)$, and $8.1 \%$ ( $p>$ 0.05 ) of the values in the WT mice in large, medium, and small neurons, respectively (Fig. $6 \mathrm{~K}$ ). In large neurons, the average numbers of APs evoked by stimulation of between 1100 and 1300 $\mathrm{pA}$ in the $\mathrm{Mbd1}^{-1-}$ mice were less than those in the WT mice (Fig. $6 \mathrm{~L}$ ), whereas, in medium neurons, the average numbers of APs evoked by the stimulation of $\leq 600 \mathrm{pA}$ in the $\mathrm{Mbd1}^{-1-}$ mice were less than those in the WT mice (Fig. 6M). No significant differences were observed in the average numbers of APs evoked by stimulation of the currents used in small neurons between the $M b d 1^{-1-}$ and WT mice (Fig. $6 \mathrm{~N}$ ). Compared with the WT mice, the $M b d 1^{-1-}$ mice also displayed significant decreases in the membrane input resistances and increases in the AP amplitudes in large, medium, and small neurons (Table 3). There were no significant differences in other AP parameters between two types of mice, such as AP threshold, AP overshoot, and afterhyperpolarization amplitude (Table 3). Together, these findings indicate that DRG MBD1 deficiency decreases basal DRG neuronal excitability.

\section{DRG MBD1 deficiency impairs MOR-coupled intracellular signals in DRG neurons and delays morphine tolerance development}

MOR regulates neuronal function and produces analgesic effects through inhibition/activation of intracellular signals, predominantly including inhibition of voltage-dependent $\mathrm{Ca}^{2+}$ current and adenylyl cyclase-mediated cAMP production and activation of G-protein-gated inwardly rectifying potassium channels. Given that G-protein-gated inwardly rectifying potassium channels are absent in mouse DRG (Nockemann et al., 2013), we observed the effect of MBD1 deficiency on MOR-coupled voltage-dependent $\mathrm{Ca}^{2+}$ and adenylyl cyclase in the cultured DRG neurons. Potassium chloride (KCl)-induced $\mathrm{Ca}^{2+}$ response from the $\mathrm{Mbd1}^{-1-}$ mice significantly decreased compared with those from WT mice (Fig. $7 A, B$ ). After bath application of DAMGO, a selective MOR agonist, the decrease in $\mathrm{KCl}$-induced $\mathrm{Ca}^{2+}$ response in DRG neurons from the $\mathrm{Mbd1}^{-1-}$ mice was greater than those from the WT mice (Fig. $7 A, B$ ). These decreases were rescued when coadministration of D-Phe-CysTyr-D-Trp-Arg-Thr-Pen-Thr-NH2 (CTAP), a selective MOR antagonist, in both mice (Fig. $7 A, B$ ). Consistently, FSK, an activator of adenylyl cyclase, led to a less increase in cAMP production in DRG neurons from the $M b d 1^{-1-}$ mice compared with that from the WT mice (Fig. 7C). DAMGO application produced a greater inhibition in cAMP production in the $\mathrm{Mbd1}^{-1-}$ mice compared with that in the WT mice (Fig. 7C). As expected, coadministration of CTAP abolished these inhibitions in both mice (Fig. 7C). The evidence indicates that MBD1 deficiency increases MOR expression, therefore enhancing the MOR-mediated inhibitions of voltage-dependent $\mathrm{Ca}^{2+}$ channel and adenylyl cyclase.

We further examined the role of DRG MBD1 in opioid analgesia. Given that morphine predominantly binding to MOR is widely used in pain management, we examined the effect of DRG MBD1 deficiency on morphine analgesia and morphine-induced analgesic tolerance. As shown in Figure 7D, after subcutaneous administration of a single low dose of morphine $(1 \mathrm{mg} / \mathrm{kg})$, the $M b d 1^{-1-}$ mice exhibited a significant increase in morphine MPAE compared with the WT mice. In line with previous reports (Liaw et al., 2008; Liang et al., 2016b), repeated subcutaneous administration of morphine $(10 \mathrm{mg} / \mathrm{kg}$, twice daily) led to morphine analgesic tolerance as demonstrated by time-dependent reductions in morphine MPAEs in the WT mice (Fig. 7E). These deductions were significantly attenuated on days $3,5,7$, and 8 after morphine injection in the $M b d 1^{-1-}$ mice (Fig. $7 E$ ). Our work indicates that MBD1 deficiency increases MOR-mediated analgesia and reduces MOR-mediated analgesic tolerance.

\section{DNMT3a participates in MBD1 regulation of MOR and Kv1.2 expression in the DRG neurons}

Finally, we explored the mechanisms of how DRG MBD1 regulated MOR and Kv1.2 expressions in the DRG neurons. We first used chromatin immunoprecipitation assays and demonstrated that a fragment within the Oprm1 promotor $(-340$ to -200$)$ or the Kcna2 promotor ( -460 to -219$)$ was amplified from the complex immunoprecipitated with an anti-MBD1 antibody (but not normal serum) in nuclear fractions from the WT mouse DRGs (Fig. 8A). These amplifications were absent in the $\mathrm{Mbd1}^{-1-}$ mice (Fig. $8 A$ ), suggesting that MBD1 specifically binds to the Oprm1 and Kcna2 genes in the DRG. Furthermore, we performed luciferase assay on CAD cells and revealed that cotransfection of $M b d 1$ vector (encoding full-length MBD1), but not control Gfp vector, dramatically reduced the transcriptional activities of the Oprm1 and Kcna2 gene promotors (including the 
A Before MTX After MTX

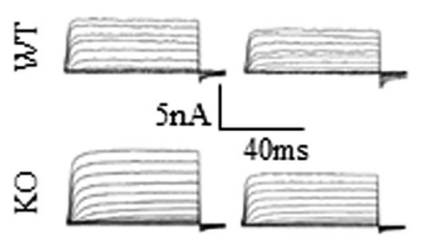

D

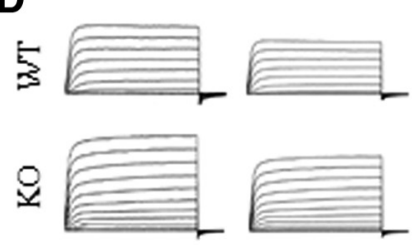

G

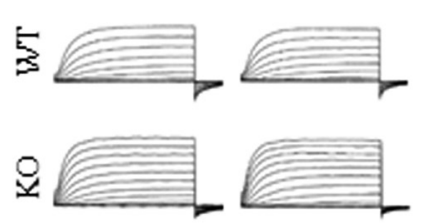

J $\square$ WT $\mathbf{~ K O ~} \mathbf{K}$

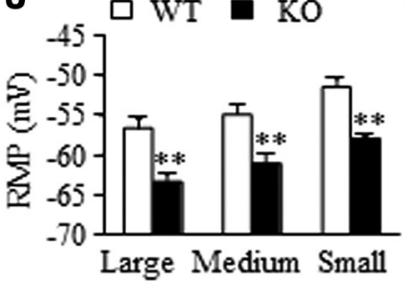

M

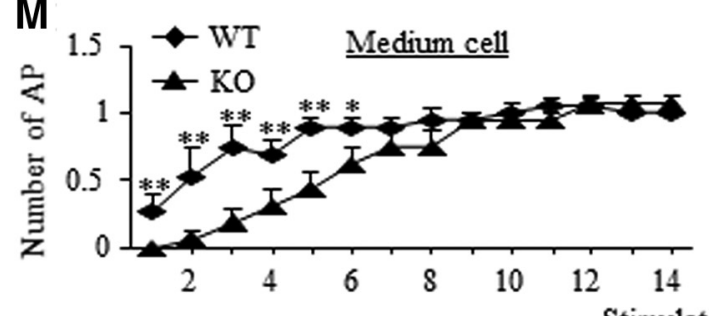

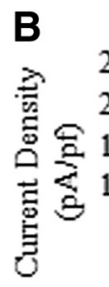

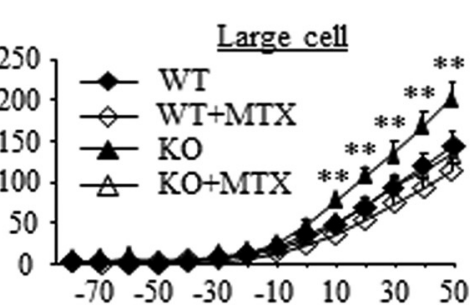

E $\quad 350$
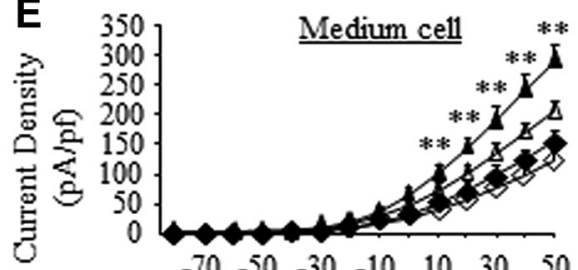

H 300
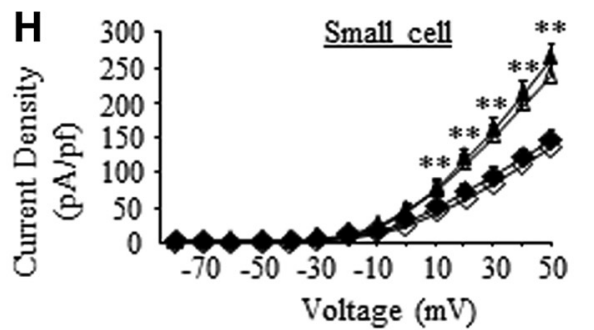

C

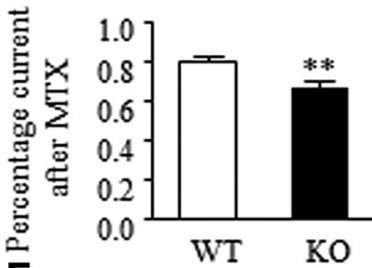

$\mathbf{F}$
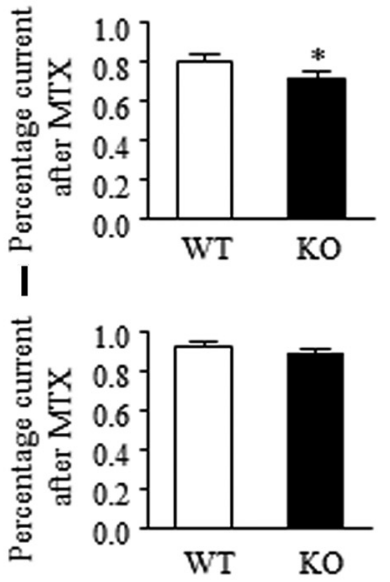
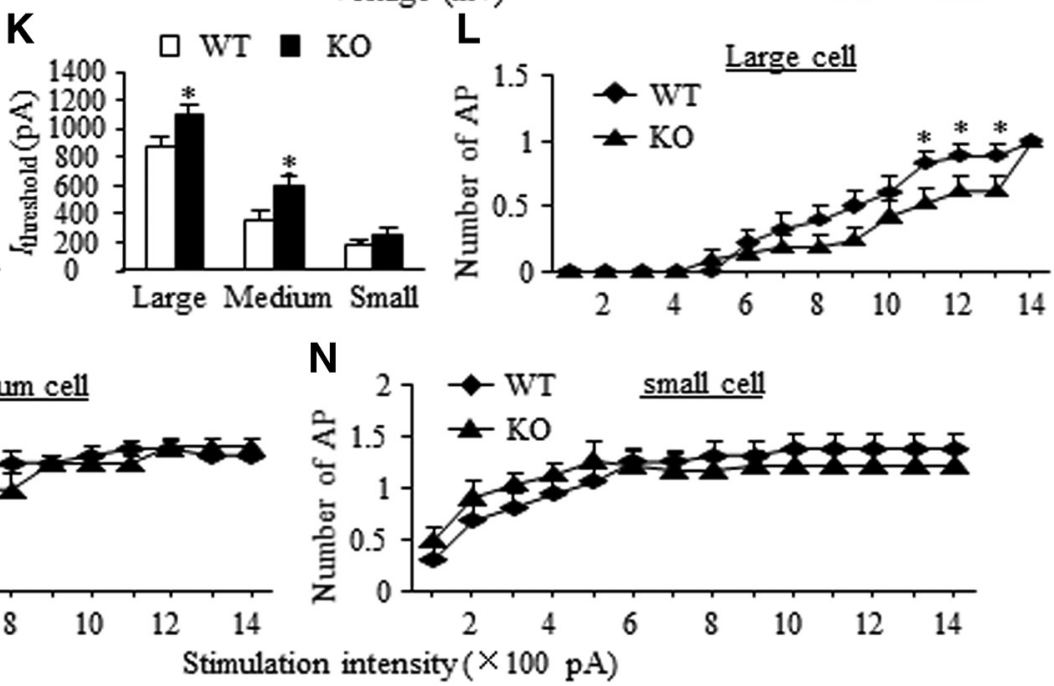

Figure 6. MBD1 deficiency increases basal total Kv current and decreases basal excitability in DRG neurons. $A$, Representative traces of total Kv currents before or after bath perfusion of $100 \mathrm{~nm}$ MTX in the large DRG neurons. $\boldsymbol{B}, I-V$ curves before or after $100 \mathrm{~nm} \mathrm{MTX}$ application in the large DRG neurons from WT ( $n=18$ neurons from 5 mice) and Mbd $1-/-$ (K0, $n=21$ neurons from 6 mice) mice. Two-way ANOVA followed by post hoc Tukey test: $F_{\text {group }(1,545)}=15.37 .{ }^{* *} p<0.01$ versus the WT mice before MTX application. $\boldsymbol{C}$, At $50 \mathrm{mV}$, reduction in total Kv current in the large DRG neurons after MTX application was greater in the Mbd1 ${ }^{-1-}$ mice than in the WT mice. ${ }^{* *} p<0.01$ versus the WT group (two-tailed unpaired Student's $t$ test). $\boldsymbol{D}$, Representative traces of total Kv currents before or after bath perfusion of $100 \mathrm{~nm}$ MTX in the medium DRG neurons. $E, I-V$ curves before or after $100 \mathrm{~nm}$ MTX application in the medium DRG neurons from WT ( $n=19$ neurons from 5 mice) and $\mathrm{Mbd1}^{-1-}\left(\mathrm{KO}, n=16\right.$ neurons from 6 mice) mice. Two-way ANOVA followed by post hoc Tukey test: $F_{\text {group }(1,489)}=29.13 .{ }^{* *} p<0.01$ versus the WT mice before MTX application. $\boldsymbol{F}$, At $50 \mathrm{mV}$, reduction in total Kv current in the medium DRG neurons after MTX treatment was greater in the Mbd ${ }^{-}{ }^{-}$mice than in the WT mice. ${ }^{*} p<0.05$ versus the WT mice (two-tailed unpaired Student's t test). G, Representative traces of total Kv currents before or after bath application of $100 \mathrm{~nm}$ MTX in the small DRG neurons. $\boldsymbol{H}, I-V$ curves before or after $100 \mathrm{~nm} \mathrm{MTX}$ application in the small DRG neurons from WT ( $n=22$ neurons from 5 mice) and $\mathrm{Mbd}^{-1-}\left(n=16\right.$ neurons from 6 mice) mice. Two-way ANOVA followed by post hoc Tukey test: $F_{\text {group }(1,541)}=0.15$. ${ }^{* *} p<0.01$ versus the WT mice before MTX application. $I$, At $50 \mathrm{mV}$, reduction in total Kv current in the small DRG neurons after MTX application in the $M b d 1{ }^{-} /-$mice was not significantly different from that in the WT mice. $\boldsymbol{J}, \boldsymbol{K}$, Resting membrane potential $(\boldsymbol{J})$ and current threshold for pulses ( $\left.\boldsymbol{I}_{\text {threshold } \boldsymbol{K}} \boldsymbol{K}\right) . n=18$ large, 19 medium, and 22 small neurons from the WT mice ( 5 mice). $n=21$ large, 16 medium, and 16 small neurons from the $M b d 1^{-1}$ mice $\left(K 0,6\right.$ mice). $J, t_{\text {large }}=4.02, t_{\text {medium }}=3.35$, and $t_{\text {small }}=4.60 . K, t_{\text {large }}=-1.73, t_{\text {medium }}=-2.67$, and $t_{\text {small }}=-1.95$. ${ }^{*} p<0.05$ versus the corresponding WT mice (two-tailed unpaired Student's $t$ test). ${ }^{* *} p<0.01$ versus the corresponding WT mice (two-tailed unpaired Student's $t$ test). $\boldsymbol{L}-\boldsymbol{N}$, Numbers of evoked APs from WT and $\mathrm{Mbd1}^{-1-}$ (KO) mice after application of different currents as indicated. Two-way ANOVA followed by post hoc Tukey test. Numbers of the recorded cells are the same as in $J$. $F_{\text {group }(1,13)}=38.05$ for large $(\boldsymbol{L}), F_{\text {group }(1,13)}=18.907$ for medium $(\boldsymbol{M})$, and $F_{\text {group }(1,13)}=8.593$ for small $(\boldsymbol{N}) .^{*} p<0.05$ versus the same stimulation intensity in the WT mice. ${ }^{* *} p<0.01$ versus the same stimulation intensity in the WT mice.

MBD1-binding fragments identified above) that were premethylated with the CpG methyltransferase (Fig. $8 B$ ). Single-cell RTPCR analysis showed coexpression of Mbd1 mRNA with Oprm1 mRNA and Kcna2 mRNA in individual small, medium, and large
DRG neurons (Fig. 8C). Our data suggest that MBD1 directly regulates the expression of Oprm1 and Kcna2 genes in DRG neurons.

MBD1 specifically recognizes and binds to unmethylated and methylated CpGs (predominantly methylated CpGs) in the re- 
Table 3. Effect of $M b d 1^{-1-}(K 0)$ on membrane input resistance $\left(R_{\text {in }}\right)$ and other AP parameters in the DRG neurons ${ }^{a}$

\begin{tabular}{|c|c|c|c|c|c|c|c|c|c|}
\hline & \multicolumn{3}{|l|}{ Large cell } & \multicolumn{3}{|l|}{ Medium cell } & \multicolumn{3}{|l|}{ Small cell } \\
\hline & WT & MBD1 K0 & $t / p$ & WT & MBD1 K0 & $t / p$ & WT & MBD1 K0 & $t / p$ \\
\hline$n$ & 18 cells, 5 mice & 21 cells, 6 mice & - & 19 cells, 5 mice & 16 cells, 6 mice & - & 22 cells, 5 mice & 16 cells, 6 mice & - \\
\hline $\mathrm{R}_{\text {in }}, \mathrm{M} \Omega$ & $75.58 \pm 22.08$ & $31.33 \pm 2.42$ & $2.152 / 0.038$ & $173.36 \pm 23.20$ & $45.68 \pm 3.52$ & $4.998 /<0.001$ & $265.99 \pm 14.24$ & $44.16 \pm 4.38$ & $-12.923 /<0.001$ \\
\hline APT, mV & $-22.08 \pm 2.56$ & $-16.24 \pm 1.25$ & $-2.144 / 0.039$ & $-31.33 \pm 3.40$ & $-16.12 \pm 0.88$ & $4.006 /<0.001$ & $-32.27 \pm 1.82$ & $-14.81 \pm 0.93$ & $-7.696 /<0.001$ \\
\hline $\mathrm{APO}, \mathrm{mV}$ & $28.22 \pm 3.69$ & $35.22 \pm 2.87$ & $-1.519 / 0.137$ & $37.03 \pm 4.11$ & $36.77 \pm 4.02$ & $-0.046 / 0.964$ & $35.99 \pm 4.39$ & $43.99 \pm 2.79$ & $-1.407 / 0.168$ \\
\hline $\mathrm{APA}, \mathrm{mV}$ & $84.42 \pm 3.83$ & $94.09 \pm 2.99$ & $2.019 / 0.051$ & $89.13 \pm 4.00$ & $93.28 \pm 3.56$ & $-0.762 / 0.451$ & $85.31 \pm 4.12$ & $97.03 \pm 2.92$ & $2.153 / 0.038$ \\
\hline AHPA, mV & $-12.36 \pm 1.13$ & $-14.53 \pm 1.38$ & $-1.196 / 0.239$ & $-14.01 \pm 1.22$ & $-15.73 \pm 2.04$ & $0.751 / 0.458$ & $-15.17 \pm 1.61$ & $-15.08 \pm 1.66$ & $0.039 / 0.969$ \\
\hline
\end{tabular}

${ }^{a}$ Values are mean \pm SEM. $R_{\text {in }}$ Membrane input resistance; APA, action potential amplitude; APT, action potential threshold; AP0, action potential overshoot; AHPA, afterhyperpolarization amplitude.
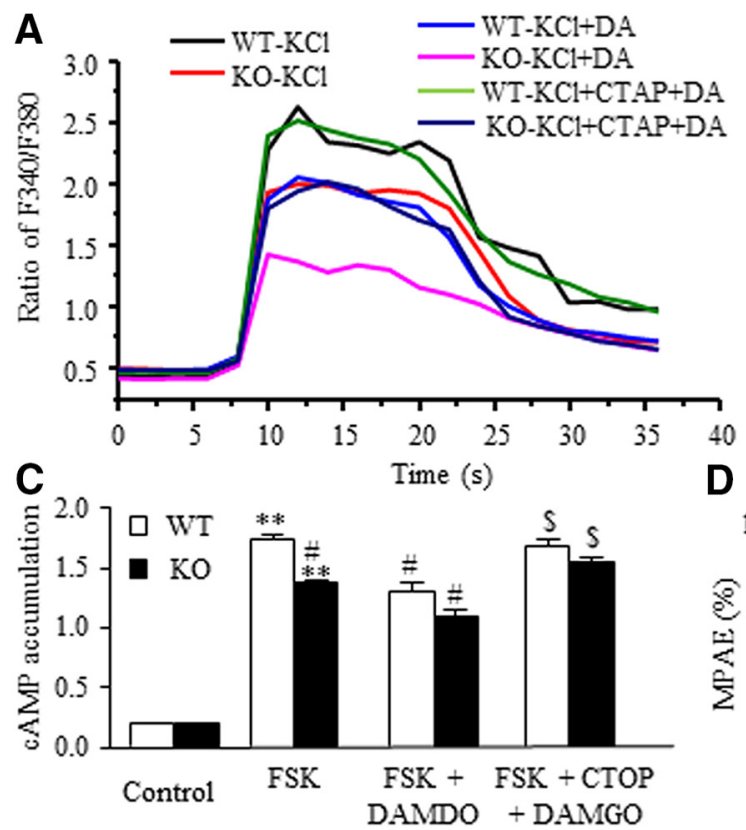

B $\quad \square$ WT-KCl $\mathbf{m O}-\mathrm{KCl}$

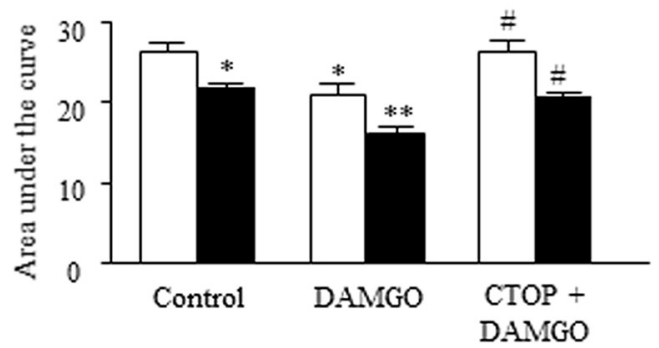

E

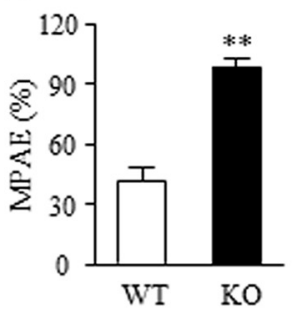

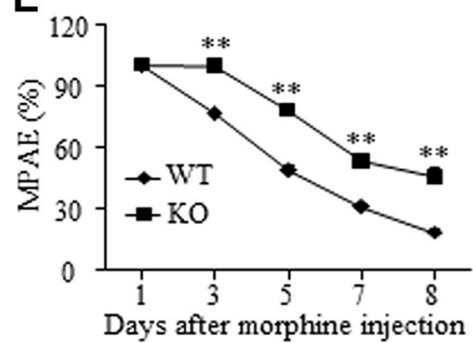

Figure 7. DRG MBD1 deficiency impairs MOR-coupled intracellular signals in DRG neurons and delays morphine tolerance development. $\boldsymbol{A}, \boldsymbol{B}$, Effect of DRG MBD1 deficiency on KCl-induced Ca $2+$ response. Representative (mean $\pm S E M)$ normalized fluorescence ratios $(340 \mathrm{~nm} / 380 \mathrm{~nm})(\boldsymbol{A})$ and areas under the curve $(\boldsymbol{B})$ in cultured DRG neurons preloaded with the ratiometric $\mathrm{Ca}^{2+}$ indicator fura-2 stimulated with $100 \mathrm{~mm} \mathrm{KCl}$ in the presence or absence of $200 \mu \mathrm{m}$ DAMG0 or DAMG0 plus $400 \mu \mathrm{m}$ (TAP application from WT and or Mbd1 1 - - (K0) mice. $n=20$ repeats. Tw0-way ANOVA followed by post hoc Tukey test: $F_{\text {group }(1,119)}=40.12$. ${ }^{*} p<0.05$ versus the $\mathrm{KCl}$-treated group from WT mice. ${ }^{* *} p<0.01$ versus the KCl-treated group from WT mice. ${ }^{*} p<0.05$ versus the corresponding DAMG0-treated group. C, Effect of DRG MBD1 deficiency on FSK-stimulated CAMP accumulation in cultured DRG neurons stimulated with $50 \mu M \mathrm{MSK}$ in the presence or absence of 160 пм DAMG0 or DAMG0 plus 400 nм CTAP application from WT and or Mbd1 ${ }^{-1-}$ (K0) mice. $n=3$ repeats. Two-way ANOVA followed by post hoc Tukey test: $F_{(1,23)}=8.71$. ${ }^{* *} p<0.01$ versus the control group from the WT mice. ${ }^{\#} p<0.05$ versus the FSK-stimulated group from the WT mice. ${ }^{\$} p<0.05$ versus the corresponding FSK plus DAMG0 group. $D$, The morphine MPAEs measured 20 min after subcutaneous injection of $1 \mathrm{mg} / \mathrm{kg}$ morphine in the WT and $M b d 1^{-} /-$(KO) mice. $n=6$ mice/group. ${ }^{* *} p<0.01$ versus the WT mice (two-tailed unpaired Student's $t$ test). $\boldsymbol{E}$, Morphine analgesic tolerance developed by subcutaneous injection of $10 \mathrm{mg} / \mathrm{kg}$ morphine twice daily for $8 \mathrm{~d}$ in the WT and Mbd $1-1-(\mathrm{KO})$ mice. MPAEs were measured 20 min after morphine injection on the mornings of days $1,3,5,7$, and 8 after injection. $n=5$ mice/group. Tw0-way ANOVA followed by post hoc Tukey test: $F_{\text {group }(1,54)}=228.24$. ${ }^{* *} p<0.01$ versus the corresponding time point in the WT mice.

gion of gene promotor to repress gene transcriptional activity possibly through recruiting other transcriptional corepressors (e.g., DNA methyltransferases) (Ng et al., 2000; J. Y. Zhao et al., 2017). We used coimmunoprecipitation assay and identified that DNMT3a antibody was able to immunoprecipitate not only itself but also MBD1 in the nuclear fraction of DRG neurons from the WT (but not $M b d 1^{-I^{-}}$) mice (Fig. 9A), suggesting specific interaction of MBD1 with DNMT3a in DRG neurons. We then overexpressed DNMT3a in the DRG neurons through transducing HSV-Dnmt3a (which expresses full-length DNMT3a) into the cultured DRG neurons from the WT and $M b d 1^{-/-}$mice (Fig. $9 B)$. HSV-GFP was used as a control. Transduction of HSVDnmt3a, but not HSV-GFP, significantly reduced the expression of both Oprm1 and Kcna2 mRNAs in the DRG neurons from the WT mice (Fig. 9B). These reductions are absent and/or overturned in both virus-transduced DRG neurons from the $M b d 1^{-1-}$ mice (Fig. 9B). Furthermore, co-overexpression of MBD1 and DNMT3a in the DRG neurons through cotransduc- tion of HSV-Dnmt3a and AAV5-Mbd1 into the cultured DRG neurons from the WT mice produced much greater reductions in expression of both Oprm1 and Kcna2 mRNAs compared with single transduction of each gene (Fig. 9C). Our single-cell RT-PCR analysis revealed coexpression of Mbd1 mRNA with Dnmt3a mRNA in individual small, medium, and large DRG neurons (Fig. 9D). These findings suggest that MBD1 functions as the transporter and recruits DNMT3a into the Oprm1 and Kcna2 gene promoters, resulting in reductions of their transcriptional activity and subsequent silence of their expression.

\section{Discussion}

Although both acute pain and neuropathic pain have been intensively investigated for several decades, how the transmission of noxious information is maintained under acute pain conditions and how pain hypersensitivities are caused under neuropathic pain conditions are still elusive. In this study, we demonstrated that DRG MBD1 deficiency produced the reduction in response 

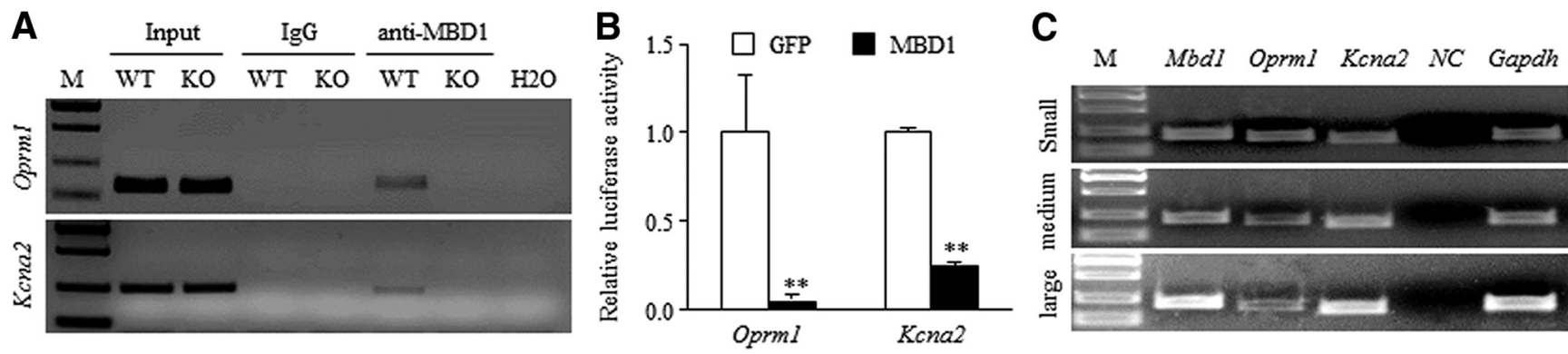

Figure 8. MBD1 regulates Oprm1 and Kcna2 gene transcriptional activities in the DRG. $A$, The fragments of Oprm1 $(-340$ to -200$)$ and Kcna2 $(-460$ to -219$)$ gene promotors were immunoprecipitated by rabbit anti-MBD1 antibody (not by normal serum lgG) in the DRGs from the WT, but not Mbd1 ${ }^{-1-}$ (KO), mice. Input, Total purified fragments; M, ladder marker. $n=3$ repeats. B, Oprm1 or Kcna2 gene promotor activity in the CAD cells cotransfected with the luciferase constructs (including Oprm1 or Kcna2 gene promotor premethylated by CpG methyltrasferase M.Sssl) with full-length Mbd1plasmid (MBD1) or Gfp plasmid (GFP). $n=3$ repeats/group. $t=2.89$ for Oprm1, $t=74.72$ for Kcna2. ${ }^{* *} p<0.01$ versus the corresponding GFP group (two-tailed unpaired Student's $t$ test). C, Coexpression of Mbd1 mRNA with Oprm 1 and Kcna2 mRNA in individual small, medium, and large DRG neurons from the mice. Gapdh mRNA was used as a positive control. M, Ladder marker. NC, Negative control (No DNA). $n=3$ repeats.
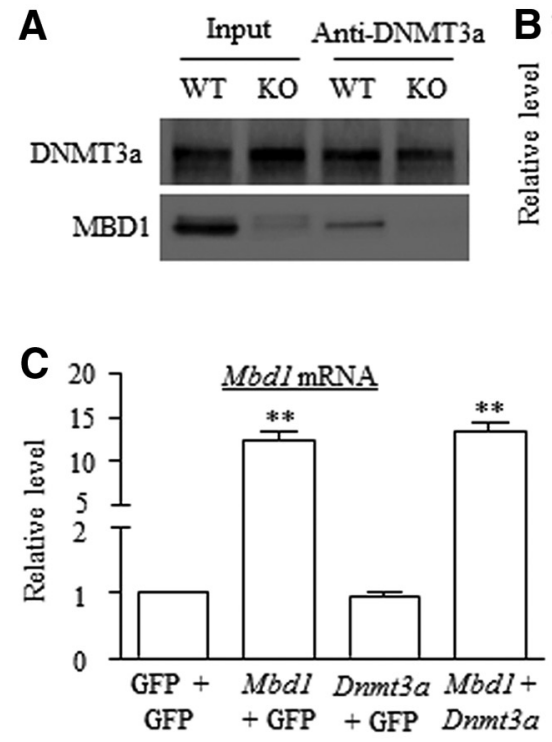

$\mathbf{D}_{\mathrm{M}}$

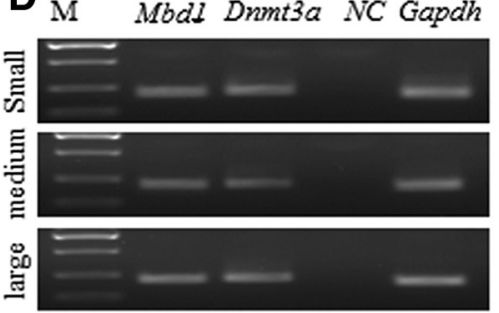

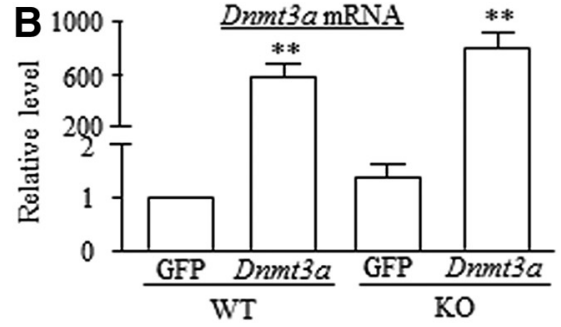
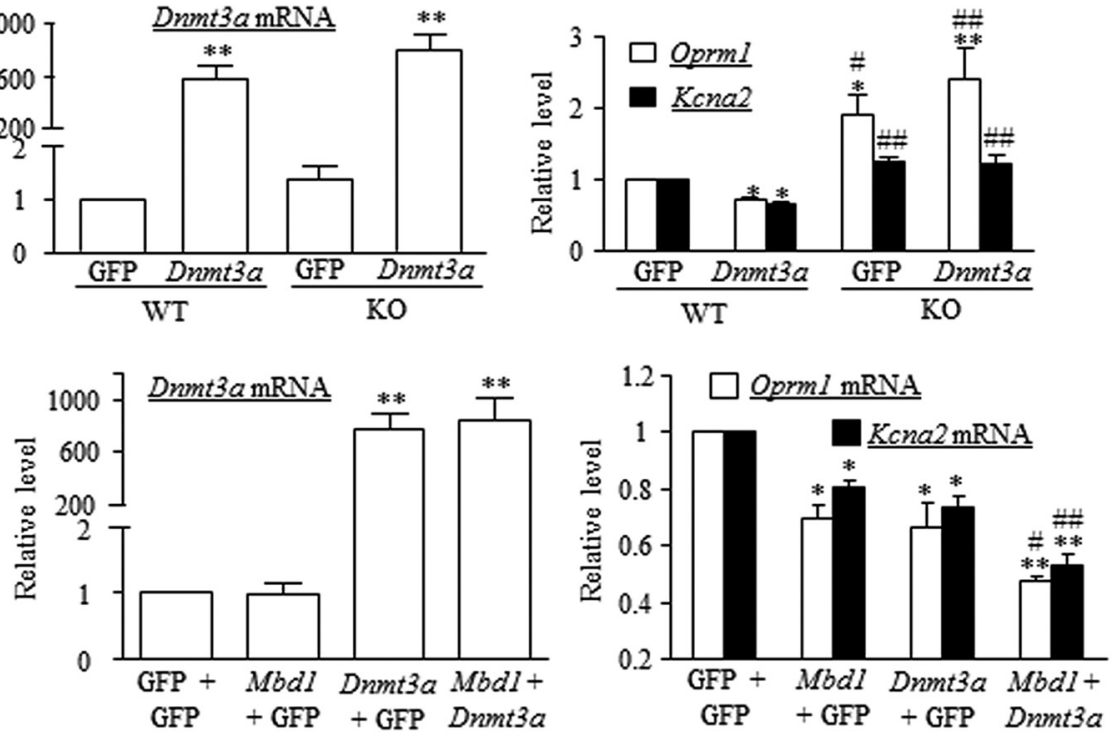

Figure 9. DNMT3a participates in MBD1 regulation of MOR and Kv1.2 expression in the DRG neurons. $A$, The binding of DNMT3a to MBD1 in the DRG. MBD1 was immunoprecipitated by rabbit anti-DNMT3a antibody in the nuclear fraction of DRG neurons from the WT, but not $M b d 1^{-1-}$, mice. $n=3$ or 4 repeats. $B$, Expression of Dnmt3a (left), Oprm 1 (right), and Kcna2 (right) mRNAs in cultured DRG neurons from WT and Mbd1 ${ }^{-1-}$ (KO) mice transfected with HSV-Gfp (GFP) or HSV-Dnmt3a (Dnmt3a). $n=3$ or 4 repeats. Two-way ANOVA followed by post hoc Tukey test, $F_{(1,11)}=$ 687346.25 for Dnmt3a mRNA, $F_{(1,15)}=44.683$ for Oprm $1 \mathrm{mRNA}$, and $F_{(1,11)}=80.36$ for Kcna2 mRNA. ${ }^{*} p<0.05$ versus the corresponding HSV-Gfp-treated group from the WT mice. ${ }^{* *} p<0.01$ versus the corresponding HSV-Gfp-treated group from the WT mice. C, Expression of Mbd1 (left), Dnmt3a (middle), and Oprm 1 (right) mRNAs in WT DRG cultured neurons cotransfected with HSV-GFP (GFP) plus AAV5-GFP (GFP), AAV5-Mbd1 (Mbd1) plus AAV5-GFP, HSV-Dnmt3a (Dnmt3a) plus AAV5-GFP, or AAV5-Mbd1 plus HSV-Dnmt3a. $n=3$ repeats. One-way ANOVA followed by post hoc Tukey test, $F_{(3,11)}=73.09$ for Mbd1 mRNA, $F_{(3,11)}=21.53$ for Dnmt3a mRNA, $F_{(3,11)}=10.38$ for Oprm $1 \mathrm{mRNA}$, and $F_{(3,11)}=40.80$ for Kcna2 mRNA. ${ }^{*} p<0.05$ versus the corresponding HSV-GFP plus AAV5-GFP group. ${ }^{* *} p<0.01$ versus the corresponding HSV-GFP plus AAV5-GFP group. ${ }^{\#} p<0.05$ versus the corresponding AAV5-Mbd1 plus HSV-GFP group. ${ }^{\# \#} p<0.01$ versus the corresponding AAV5-Mbd1 plus HSV-GFP group. D, Coexpression of Mbd1 mRNA with Dnmt3a mRNA in individual small, medium, and large neurons from the mouse DRG. $n=3$ repeats.

to acute noxious stimuli and the attenuation of pain hypersensitivities following peripheral nerve injury. DRG overexpression of MBD1 led to higher sensitive responses to noxious stimuli. Mechanistically, MBD1 repressed MOR and Kv1.2 expression by recruiting DNMT3a into the promoter of the Oprm1 and Kcna2 genes in DRG neurons. Given that DRG deficiency of MOR or
Kv1.2 contributes to the genesis of acute pain and neuropathic pain (Mansikka et al., 2004; X. Zhao et al., 2013; Fan et al., 2014; Klein et al., 2018), MBD1 likely participates in the mechanisms that underlie these disorders.

MBD1-controlled expression of MOR and Kv1.2 in the DRG is required for maintaining transmission of normal sensory or 
acute noxious information. MOR KO mice exhibited enhanced response to mechanical stimulation on uninjured paw in addition to increased mechanical allodynia on injured paw of neuropathic pain rats (Mansikka et al., 2004). DRG Kv1.2 knockdown increased the excitability in large and medium DRG neurons and produced heightened responses to mechanical and cold stimuli in naive rats (X. Zhao et al., 2013). The evidence indicates that maintaining intact expression of MOR and Kv1.2 in the DRG is important for the transmission of normal sensory or acute noxious information. We showed here that the $M b d 1^{-1-}$ mice displayed the increases in the levels of MOR and Kv1.2 proteins, but not KOR and Kv1.1 proteins, in DRG. The selectively targeting genes of MBD1 may be interpreted by its unique methyl-CpG binding domain (Clouaire et al., 2010), which may bind more efficiently to methylated DNA within a specific sequence context in the promoter regions of the targeted genes. How basal levels of MOR and Kv1.2 proteins in spinal cord and other brain regions are unchanged in the $M b d 1^{-1-}$ mice are unclear and may be related to potential confounding and compensatory factors in the $M b d 1^{-1-}$ mice. To further confirm the role of MBD1 in regulation of MOR and Kv1.2 basal expression in DRG, we microinjected Mbd1 siRNA into the DRGs and revealed that transient knockdown of DRG MBD1 increased basal levels of DRG MOR and Kv1.2. Like the $M b d 1^{-1-}$ mice, the Mbdl siRNA-treated mice displayed the decreased responses to mechanical, heat, and cold stimuli. Moreover, MBD1 deficiency increased basal Kv1.2mediated current and reduced basal excitability in large and medium DRG neurons and produced an inhibition of MORcoupled intracellular signals in DRG neurons. In addition, DRG overexpression of MBD1 reduced the levels of DRG MOR and Kv1.2 and produced the aggressive responses to mechanical, heat, and cold stimuli and spontaneous pain in naive mice. Rescuing MBD1 expression in the $M b d 1^{-/-}$mouse DRGs blocked MBD1 deficiency-induced increases in DRG MOR and Kv1.2 and restored normal responses to acute mechanical, heat, and cold stimuli. Given that MBD1 binds to the promoters of both Oprm1 and Kcna2 genes and that Mbd1, Oprm1, and Kcna2 mRNAs coexpress in the individual small, medium, and large DRG neurons, our findings suggest that DRG MBD1 is required for maintaining the transmission of normal sensory and/or acute noxious information likely through its controlling expression of DRG MOR and Kv1.2. It should be noted that MBD1 may also regulate other pain-related genes. For example, MBD1 regulates the location and activity of Tet1 (Zhang et al., 2017; Klein et al., 2018), whereas SNL-enhanced Tet1 expression contributed to neuropathic pain through epigenetic modification of BDNF expression in dorsal horn neurons (Hsieh et al., 2016; Klein et al., 2018). Thus, whether other potential pain-related genes regulated by MBD1 participate in maintaining the transmission of normal sensory and/or acute noxious information remains to be further investigated.

DRG MBD1 is also required for nerve injury-induced pain hypersensitivities through its participation in downregulation of DRG MOR and Kv1.2. It is well documented that nerve injuryinduced downregulation of DRG MOR and Kv1.2 contributes to neuropathic pain genesis. MOR downregulation in the injured DRG augments the release of primary afferent neurotransmitters following peripheral nerve injury (Liang et al., 2016b; Sun et al., 2017). Nerve injury-induced Kv1.2 downregulation in the injured medium and large DRG neurons leads to the hyperexcitability of these neurons (X. Zhao et al., 2013; Fan et al., 2014; Li et al., 2015, 2017). Rescuing both downregulations alleviates neuropathic pain (X. Zhao et al., 2013; Li et al., 2015, 2017; Klein et al., 2018). This study showed that blocking nerve injury-induced increase of MBD1 in the injured DRG through its congenital KO or transient knockdown rescued nerve injury-induced downregulation of MOR and Kv1.2 in the injured DRG and impaired neuropathic pain. The evidence suggests that increased MBD1 in the DRG contributes to neuropathic pain development at least in part through the mechanism of its involvement in downregulation of the MOR and Kv1.2 in the injured DRG. However, as in acute pain discussed above, participation of DRG MBD1 in neuropathic pain through its regulation of other potential painrelated genes cannot be ruled out. Given that DRG MBD1 deficiency increased Kv1.2-independent $\mathrm{Kv}$ current, reduced resting membrane, and increased current threshold in small DRG neurons, MBD1 likely regulates other Kv channel expression in small DRG neurons, although these Kv channel changes did not affect basal excitability of small DRG neurons. In addition, unlike DRG Kv1.2 knockdown, DRG MBD1 deficiency increased the membrane input resistances and increased the AP amplitudes in all DRG neurons. This suggests that MBD1 may control the expression of non-Kv channel genes. Our study also revealed that congenital KO or transient knockdown of DRG MBD1 attenuated CFA-induced pain hypersensitivities and formalin-induced pain behaviors. Given that CFA or formalin injection did not alter the expression of MBD1 (data not shown) as well as MOR (Lee et al., 2011) and Kv1.2 (Fan et al., 2014) in the DRG, how $\mathrm{MBD} 1$ participates in inflammatory pain remains to be further determined.

DNMT3a participates in MBD1-controlled expression of DRG MOR and Kv1.2 under the conditions of acute pain and neuropathic pain. We previously reported that DNMT3a interacted with the promoters of Oprm1 and Kcna2 genes and repressed their transcriptional activities in DRG neurons (Sun et al., 2017; J. Y. Zhao et al., 2017). DNMT3a also coexpressed with MOR and Kv1.2 in the individual DRG neurons (Sun et al., 2017; J. Y. Zhao et al., 2017). Moreover, MBD1 was required for DNMT3a binding to the Oprm1 gene in the DRG (Sun et al., 2017). In this study, we reported that MBD1 not only bond to the promoters of Oprm1 and Kcna2 genes but also interacted with DNMT3a in the DRG. Mbd1 mRNA coexpressed with Dnmt3a mRNA in addition to Oprm1 and Kcna2 mRNAs in the individual small, medium, and large DRG neurons. We conclude that, under acute pain conditions, MBD1 deficiency likely fails to recruit basal DNMT3a into the promoter regions of Oprm1 and Kcna2 genes, resulting in the disinhibition of these two gene transcriptional activities and subsequent increases of basal MOR and Kv1.2 expression in the DRG neurons and a reduction in response to acute noxious stimulation. Under neuropathic pain conditions, due to nerve injury-induced increases in expression of both MBD1 and DNMT3a in the injured DRG (Sun et al., 2017), the increased MBD1 recruits more DNMT3a into the promoter regions of Oprm1 and Kcna2 genes, resulting in the silence of their expression and the induction of pain hypersensitivity following nerve injury. These conclusions are strongly supported by our in vitro observations that showed that, unlikely in the cultured neurons from WT mice, the levels of MOR and Kv1.2 were increased instead following DRG DNMT3a overexpression in the cultured DRG neurons from the $M b d 1^{-1-}$ mice and that co-overexpression of MBD1 and DNMT3a enhanced the inhibition of both MOR and Kv1.2 expression in the DRG neurons. The evidence demonstrates the synergism between MBD1 and DNMT3a to control expression of MOR and Kv1.2 in the DRG.

In conclusion, our study, for the first time, revealed an epigenetic mechanism of MBD1-controlled DRG MOR and Kv1.2 ex- 
pressions under the conditions of acute pain and neuropathic pain. Given that DRG MOR and Kv1.2 are key players in neuropathic pain initiation and maintenance (Sun et al., 2017; J. Y. Zhao et al., 2017) and that blocking-increased MBD1 not only rescues MOR and Kv1.2 expression in the injured DRG but also alleviated nerve injury-induced neuropathic pain, MBD1 may be an endogenous initiator of neuropathic pain and could be a potential target for the prevention and treatment of this disorder. Because MBD1 is also required for acute pain, blocking-increased MBD1 expression in neuropathic pain management should be adjusted adequately to avoid an alteration of acute pain.

\section{References}

Alvarado S, Tajerian M, Millecamps M, Suderman M, Stone LS, Szyf M (2013) Peripheral nerve injury is accompanied by chronic transcriptome-wide changes in the mouse prefrontal cortex. Mol Pain 9:21. CrossRef Medline

Chu YC, Guan Y, Skinner J, Raja SN, Johns RA, Tao YX (2005) Effect of genetic knockout or pharmacologic inhibition of neuronal nitric oxide synthase on complete Freund's adjuvant-induced persistent pain. Pain 119:113-123. CrossRef Medline

Clouaire T, de Las Heras JI, Merusi C, Stancheva I (2010) Recruitment of $\mathrm{MBD} 1$ to target genes requires sequence-specific interaction of the MBD domain with methylated DNA. Nucleic Acids Res 38:4620-4634. CrossRef Medline

Collin E, Frechilla D, Pohl M, Bourgoin S, Le Bars D, Hamon M, Cesselin F (1993) Opioid control of the release of calcitonin gene-related peptidelike material from the rat spinal cord in vivo. Brain Res 609:211-222. CrossRef Medline

Cuddapah VA, Pillai RB, Shekar KV, Lane JB, Motil KJ, Skinner SA, Tarquinio DC, Glaze DG, McGwin G, Kaufmann WE, Percy AK, Neul JL, Olsen ML (2014) Methyl-CpG-binding protein 2 (MECP2) mutation type is associated with disease severity in Rett syndrome. J Med Genet 51:152-158. CrossRef Medline

Cui L, Miao X, Liang L, Abdus-Saboor I, Olson W, Fleming MS, Ma M, Tao YX, Luo W (2016) Identification of early $\mathrm{RET}^{+}$deep dorsal spinal cord interneurons in gating pain. Neuron 91:1137-1153. CrossRef Medline

Descalzi G, Mitsi V, Purushothaman I, Gaspari S, Avrampou K, Loh YE, Shen L, Zachariou V (2017) Neuropathic pain promotes adaptive changes in gene expression in brain networks involved in stress and depression. Sci Signal 10:eaaj1549. CrossRef Medline

Downs J, Géranton SM, Bebbington A, Jacoby P, Bahi-Buisson N, Ravine D, Leonard H (2010) Linking MECP2 and pain sensitivity: the example of Rett syndrome. Am J Med Genet A 152A:1197-1205. CrossRef Medline

Fan L, Guan X, Wang W, Zhao JY, Zhang H, Tiwari V, Hoffman PN, Li M, Tao YX (2014) Impaired neuropathic pain and preserved acute pain in rats overexpressing voltage-gated potassium channel subunit Kv1.2 in primary afferent neurons. Mol Pain 10:8. CrossRef Medline

Géranton SM, Fratto V, Tochiki KK, Hunt SP (2008) Descending serotonergic controls regulate inflammation-induced mechanical sensitivity and methyl-CpG-binding protein 2 phosphorylation in the rat superficial dorsal horn. Mol Pain 4:35. CrossRef Medline

Han L, Ma C, Liu Q, Weng HJ, Cui Y, Tang Z, Kim Y, Nie H, Qu L, Patel KN, Li Z, McNeil B, He S, Guan Y, Xiao B, Lamotte RH, Dong X (2013) A subpopulation of nociceptors specifically linked to itch. Nat Neurosci 16:174-182. CrossRef Medline

Heinke B, Gingl E, Sandkühler J (2011) Multiple targets of $\mu$-opioid receptor-mediated presynaptic inhibition at primary afferent $\mathrm{A} \delta$ - and C-fibers. J Neurosci 31:1313-1322. CrossRef Medline

Hsieh MC, Lai CY, Ho YC, Wang HH, Cheng JK, Chau YP, Peng HY (2016) Tet1-dependent epigenetic modification of BDNF expression in dorsal horn neurons mediates neuropathic pain in rats. Sci Rep 6:37411. CrossRef Medline

Jeltsch A (2006) Molecular enzymology of mammalian DNA methyltransferases. Curr Top Microbiol Immunol 301:203-225. Medline

Klein AH, Mohammad HK, Ali R, Peper B, Wilson SP, Raja SN, Ringkamp M, Sweitzer S (2018) Overexpression of micro-opioid receptors in peripheral afferents, but not in combination with enkephalin, decreases neuropathic pain behavior and enhances opioid analgesia in mouse. Anesthesiology 128:967-983. CrossRef Medline

Lee CY, Perez FM, Wang W, Guan X, Zhao X, Fisher JL, Guan Y, Sweitzer SM,
Raja SN, Tao YX (2011) Dynamic temporal and spatial regulation of mu opioid receptor expression in primary afferent neurons following spinal nerve injury. Eur J Pain 15:669-675. CrossRef Medline

Li Z, Gu X, Sun L, Wu S, Liang L, Cao J, Lutz BM, Bekker A, Zhang W, Tao YX (2015) Dorsal root ganglion myeloid zinc finger protein 1 contributes to neuropathic pain after peripheral nerve trauma. Pain 156:711-721. CrossRef Medline

Li Z, Mao Y, Liang L, Wu S, Yuan J, Mo K, Cai W, Mao Q, Cao J, Bekker A, Zhang W, Tao YX (2017) The transcription factor C/EBPbeta in the dorsal root ganglion contributes to peripheral nerve trauma-induced nociceptive hypersensitivity. Sci Signal 10:eaam5345. CrossRef Medline

Liang L, Lutz BM, Bekker A, Tao YX (2015) Epigenetic regulation of chronic pain. Epigenomics 7:235-245. CrossRef Medline

Liang L, Gu X, Zhao JY, Wu S, Miao X, Xiao J, Mo K, Zhang J, Lutz BM, Bekker A, Tao YX (2016a) G9a participates in nerve injury-induced Kcna2 downregulation in primary sensory neurons. Sci Rep 6:37704. CrossRef Medline

Liang L, Zhao JY, Gu X, Wu S, Mo K, Xiong M, Bekker A, Tao YX (2016b) G9a inhibits CREB-triggered expression of mu opioid receptor in primary sensory neurons following peripheral nerve injury. Mol Pain 12: 1744806916682242. CrossRef Medline

Liaw WJ, Stephens RL Jr, Binns BC, Chu Y, Sepkuty JP, Johns RA, Rothstein JD, Tao YX (2005) Spinal glutamate uptake is critical for maintaining normal sensory transmission in rat spinal cord. Pain 115:60-70. CrossRef Medline

Liaw WJ, Zhu XG, Yaster M, Johns RA, Gauda EB, Tao YX (2008) Distinct expression of synaptic NR2A and NR2B in the central nervous system and impaired morphine tolerance and physical dependence in mice deficient in postsynaptic density-93 protein. Mol Pain 4:45. CrossRef Medline

Lukacs V, Yudin Y, Hammond GR, Sharma E, Fukami K, Rohacs T (2013) Distinctive changes in plasma membrane phosphoinositides underlie differential regulation of TRPV1 in nociceptive neurons. J Neurosci 33: 11451-11463. CrossRef Medline

Lutz BM, Bekker A, Tao YX (2014) Noncoding RNAs: new players in chronic pain. Anesthesiology 121:409-417. CrossRef Medline

Manners MT, Tian Y, Zhou Z, Ajit SK (2015) MicroRNAs downregulated in neuropathic pain regulate $\mathrm{MeCP} 2$ and $\mathrm{BDNF}$ related to pain sensitivity. FEBS Open Bio 5:733-740. CrossRef Medline

Mansikka H, Zhao C, Sheth RN, Sora I, Uhl G, Raja SN (2004) Nerve injury induces a tonic bilateral mu-opioid receptor-mediated inhibitory effect on mechanical allodynia in mice. Anesthesiology 100:912-921. CrossRef Medline

Mauck M, Van de Ven T, Shaw AD (2014) Epigenetics of chronic pain after thoracic surgery. Curr Opin Anaesthesiol 27:1-5. CrossRef Medline

$\mathrm{Ng} \mathrm{HH}$, Jeppesen P, Bird A (2000) Active repression of methylated genes by the chromosomal protein MBD1. Mol Cell Biol 20:1394-1406. CrossRef Medline

Nockemann D, Rouault M, Labuz D, Hublitz P, McKnelly K, Reis FC, Stein C, Heppenstall PA (2013) The $\mathrm{K}(+)$ channel GIRK2 is both necessary and sufficient for peripheral opioid-mediated analgesia. EMBO Mol Med 5:1263-1277. CrossRef Medline

Orefice LL, Zimmerman AL, Chirila AM, Sleboda SJ, Head JP, Ginty DD (2016) Peripheral mechanosensory neuron dysfunction underlies tactile and behavioral deficits in mouse models of ASDs. Cell 166:299-313. CrossRef Medline

Park JS, Voitenko N, Petralia RS, Guan X, Xu JT, Steinberg JP, Takamiya K, Sotnik A, Kopach O, Huganir RL, Tao YX (2009) Persistent inflammation induces GluR2 internalization via NMDA receptor-triggered PKC activation in dorsal horn neurons. J Neurosci 29:3206-3219. CrossRef Medline

Poetsch AR, Plass C (2011) Transcriptional regulation by DNA methylation. Cancer Treat Rev 37 [Suppl 1]:S8-S12. CrossRef Medline

Pohl M, Lombard MC, Bourgoin S, Carayon A, Benoliel JJ, Mauborgne A, Besson JM, Hamon M, Cesselin F (1989) Opioid control of the in vitro release of calcitonin gene-related peptide from primary afferent fibres projecting in the rat cervical cord. Neuropeptides 14:151-159. CrossRef Medline

Qi F, Zhou Y, Xiao Y, Tao J, Gu J, Jiang X, Xu GY (2013) Promoter demethylation of cystathionine-beta-synthetase gene contributes to inflammatory pain in rats. Pain 154:34-45. CrossRef Medline

Rigaud M, Gemes G, Barabas ME, Chernoff DI, Abram SE, Stucky CL, Hogan QH (2008) Species and strain differences in rodent sciatic nerve anat- 
omy: implications for studies of neuropathic pain. Pain 136:188-201. CrossRef Medline

Siedlecki P, Zielenkiewicz P (2006) Mammalian DNA methyltransferases. Acta Biochim Pol 53:245-256. Medline

Sun L, Zhao JY, Gu X, Liang L, Wu S, Mo K, Feng J, Guo W, Zhang J, Bekker A, Zhao X, Nestler EJ, Tao YX (2017) Nerve injury-induced epigenetic silencing of opioid receptors controlled by DNMT3a in primary afferent neurons. Pain 158:1153-1165. CrossRef Medline

Suzuki A, Shinoda M, Honda K, Shirakawa T, Iwata K (2016) Regulation of transient receptor potential vanilloid 1 expression in trigeminal ganglion neurons via methyl-CpG binding protein 2 signaling contributes tongue heat sensitivity and inflammatory hyperalgesia in mice. Mol Pain 12: 1744806916633206. CrossRef Medline

Taddese A, Nah SY, McCleskey EW (1995) Selective opioid inhibition of small nociceptive neurons. Science 270:1366-1369. CrossRef Medline

Tao YX, Rumbaugh G, Wang GD, Petralia RS, Zhao C, Kauer FW, Tao F, Zhuo M, Wenthold RJ, Raja SN, Huganir RL, Bredt DS, Johns RA (2003) Impaired NMDA receptor-mediated postsynaptic function and blunted NMDA receptor-dependent persistent pain in mice lacking postsynaptic density-93 protein. J Neurosci 23:6703-6712. CrossRef Medline

Tao YX, Gu J, Stephens RL Jr (2005) Role of spinal cord glutamate transporter during normal sensory transmission and pathological pain states. Mol Pain 1:30. CrossRef Medline

Thyagarajan B, Benn BS, Christakos S, Rohacs T (2009) Phospholipase $\mathrm{C}$-mediated regulation of transient receptor potential vanilloid 6 channels: implications in active intestinal $\mathrm{Ca}^{2+}$ transport. Mol Pharmacol 75:608-616. CrossRef Medline

Tochiki KK, Cunningham J, Hunt SP, Géranton SM (2012) The expression of spinal methyl-CpG-binding protein 2, DNA methyltransferases and histone deacetylases is modulated in persistent pain states. Mol Pain 8:14. CrossRef Medline

Turek-Plewa J, Jagodzinski PP (2005) The role of mammalian DNA methyltransferases in the regulation of gene expression. Cell Mol Biol Lett 10:631-647. Medline

Udina E, Ladak A, Furey M, Brushart T, Tyreman N, Gordon T (2010) Rolipram-induced elevation of cAMP or chondroitinase ABC breakdown of inhibitory proteoglycans in the extracellular matrix promotes peripheral nerve regeneration. Exp Neurol 223:143-152. CrossRef Medline

Vetter I, Wyse BD, Monteith GR, Roberts-Thomson SJ, Cabot PJ (2006) The $\mu$ opioid agonist morphine modulates potentiation of capsaicinevoked TRPV1 responses through a cyclic AMP-dependent protein kinase A pathway. Mol Pain 2:22. CrossRef Medline

Wang Y, Liu C, Guo QL, Yan JQ, Zhu XY, Huang CS, Zou WY (2011) Intrathecal 5-azacytidine inhibits global DNA methylation and methylCpG-binding protein 2 expression and alleviates neuropathic pain in rats following chronic constriction injury. Brain Res 1418:64-69. CrossRef Medline

Wang Y, Lin ZP, Zheng HZ, Zhang S, Zhang ZL, Chen Y, You YS, Yang MH
(2016) Abnormal DNA methylation in the lumbar spinal cord following chronic constriction injury in rats. Neurosci Lett 610:1-5. CrossRef Medline

Wu S, Marie LB, Miao X, Liang L, Mo K, Chang YJ, Du P, Soteropoulos P, Tian B, Kaufman AG, Bekker A, Hu Y, Tao YX (2016) Dorsal root ganglion transcriptome analysis following peripheral nerve injury in mice. Mol Pain 12:1-14. CrossRef Medline

Xu B, Cao J, Zhang J, Jia S, Wu S, Mo K, Wei G, Liang L, Miao X, Bekker A, Tao YX (2017) Role of microRNA-143 in nerve injury-induced upregulation of Dnmt3a expression in primary sensory neurons. Front Mol Neurosci 10:350. CrossRef Medline

Xu M, Song P, Huang W, He R, He Y, Zhou X, Gu Y, Pan S, Hu Y (2017) Disruption of AT-hook 1 domain in $\mathrm{MeCP} 2$ protein caused behavioral abnormality in mice. Biochim Biophys Acta 1864:347-358. CrossRef Medline

Yin K, Deuis JR, Lewis RJ, Vetter I (2016) Transcriptomic and behavioural characterisation of a mouse model of burn pain identify the cholecystokinin 2 receptor as an analgesic target. Mol Pain 12:1744806916665366. CrossRef Medline

Zhang P, Rausch C, Hastert FD, Boneva B, Filatova A, Patil SJ, Nuber UA, Gao Y, Zhao X, Cardoso MC (2017) Methyl-CpG binding domain protein 1 regulates localization and activity of Tet1 in a CXXC3 domain-dependent manner. Nucleic Acids Res 45:7118-7136. CrossRef Medline

Zhang R, Huang M, Cao Z, Qi J, Qiu Z, Chiang LY (2015) MeCP2 plays an analgesic role in pain transmission through regulating CREB / miR-132 pathway. Mol Pain 11:19. CrossRef Medline

Zhao CS, Tao YX, Tall JM, Donovan DM, Meyer RA, Raja SN (2003) Role of micro-opioid receptors in formalin-induced pain behavior in mice. Exp Neurol 184:839-845. CrossRef Medline

Zhao JY, Liang L, Gu X, Li Z, Wu S, Sun L, Atianjoh FE, Feng J, Mo K, Jia S, Lutz BM, Bekker A, Nestler EJ, Tao YX (2017) DNA methyltransferase DNMT3a contributes to neuropathic pain by repressing Kcna2 in primary afferent neurons. Nat Commun 8:14712. CrossRef Medline

Zhao X, Ueba T, Christie BR, Barkho B, McConnell MJ, Nakashima K, Lein ES, Eadie BD, Willhoite AR, Muotri AR, Summers RG, Chun J, Lee KF, Gage FH (2003) Mice lacking methyl-CpG binding protein 1 have deficits in adult neurogenesis and hippocampal function. Proc Natl Acad Sci U S A 100:6777-6782. CrossRef Medline

Zhao X, Tang Z, Zhang H, Atianjoh FE, Zhao JY, Liang L, Wang W, Guan X, Kao SC, Tiwari V, Gao YJ, Hoffman PN, Cui H, Li M, Dong X, Tao YX (2013) A long noncoding RNA contributes to neuropathic pain by silencing Kcna2 in primary afferent neurons. Nat Neurosci 16:1024-1031. CrossRef Medline

Zhou XL, Yu LN, Wang Y, Tang LH, Peng YN, Cao JL, Yan M (2014) Increased methylation of the MOR gene proximal promoter in primary sensory neurons plays a crucial role in the decreased analgesic effect of opioids in neuropathic pain. Mol Pain 10:51. CrossRef Medline 